\title{
„Movement reactions” in the Hermann Rorschach Test. Part 2 Testing parents of a child suffering from schizophrenia and parents of healthy children
}

\author{
Wypowiedzi „ruchowe” w teście Rorschacha. Część 2 \\ Badanie rodziców mających chore na schizofrenię dziecko oraz rodziców posiadających tylko \\ zdrowe dzieci
}

Anna Hunca - Bednarska ABCDEF

The MONAR Association - Addiction Therapy and Prevention Clinic in Lublin

\begin{abstract}
Introduction: The specific character of Rorschach test responses of parents who had a child with schizophrenia has been reported many times. The analysis presented in this paper is focused on responses commenting on movement seen in the inkblots. According to Zygmunt Piotrowski, these responses reflect the prototypal role - self-concepts and a certain pattern of responding that can be understood as phenomena related to the concept of self.

Material and method: I used the Rorschach test to examine 32 couples of parents who had a child suffering from paranoid schizophrenia (as defined in DSM-IV) and 21 couples of parents who had only healthy children.

Results: Parents of schizophrenic children gave significantly fewer human movement responses than parents of healthy children, and some features of these responses give them a specific character. The groups of fathers differed from each other to a greater degree than the groups of mothers. The analysis of relationships between movement responses and shading (chiaroscuro) responses, which are regarded as a measure of anxiety, revealed significant associations in the case of some movement qualities. The exception was that movement quality which is referred to as blocked movemen tand blocked-posture movement in Piotrowski's interpretive scheme. All movement qualities globally considered were significantly correlated with anxiety, the exceptions being the group of parents of healthy children and the group of all fathers.

Discussion: The smaller number of human movement responses found in the group of parents of schizophrenic children may attest to these people's lower psychological maturity, which is associated with a less distinctly formed prototypal role. Moreover, certain specific features of these responses can be interpreted as a sign of difficulties in expressing this role. The cooccurrence of movement responses with shading responses, which are treated as a sign of anxiety, was not always consistent with expectations; this should be considered a reason to reflect on the psychological meaning of these responses and on the possible return to Rorschach's original views.

Conclusions: The results of the study suggest lower maturity in the case of parents of schizophrenic children, manifesting itself in a less strongly developed prototypal role and certain difficulties in expressing this role. Based on the analysis of the cooccurrence of movement responses and responses commenting on the shading present in the inkblots, it is possible to conclude that there is a need for a new psychological interpretation of these responses.
\end{abstract}

Keywords: Rorschach test, schizophrenia, prototypal role, endophenotype

\section{Streszczenie}

Wstęp: Wielokrotnie stwierdzano swoistość wypowiedzi rodziców mających chore na schizofrenię dziecko gdy poddawano ich badaniu testem Hermanna Rorschacha. Prezentowana w tym artykule analiza koncentruje się na wypowiedziach mówiących o ruchu widzianym w plamach atramentowych. Wypowiedzi te według Zygmunta Piotrowskiego odzwierciedlają rolę prototypową, czyli koncepcje siebie i pewien wzorzec reagowania, które można rozumieć jako zjawiska pokrewne pojęciu selfu. Rolę prototypową można oceniać, analizując wypowiedzi mówiące o ruchu a uzyskane podczas badania testem Rorschacha. Dane empiryczne sugerują, że chorzy na schizofrenię mają niewystarczająco wykształconą lub swoiście ukształtowaną rolę prototypową, a także pewne trudności w ekspresji tej roli.

Materiał i metoda: Przebadałam za pomocą testu Rorschacha 32 pary rodziców mających dziecko chore na schizofrenię 
paranoidalną (według DSM-IV) oraz 21 par rodziców mających tylko zdrowe dzieci.

Wyniki: Rodzice dzieci chorych dali istotnie mniej wypowiedzi mówiacych o ruchu ludzkim niż rodzice dzieci zdrowych a niektóre cechy tych wypowiedzi wykazały pewną swoistość. Grupy ojców bardziej różniły się między sobą niż grupy matek. Przeprowadzona analiza związków miedzy wypowiedziami „ruchowymi” a wypowiedziami „światłocieniowymi”, które uważa się za miarę lęku, ujawniła istotne związki między lękiem a niektórymi jakościami ruchu. Wyjątkiem była ta jakość ruchu, która w systemie interpretacyjnym Piotrowskiego jest nazwana ruchem niezdecydowanym i ruchem niezdecydowanym w formie postawy. Wszystkie jakości ruchu wzięte globalnie korelowały istotnie z lękiem, wyjątkiem była tu jednak grupa rodziców zdrowych dzieci oraz grupa wszystkich ojców.

Dyskusja: Mniejsza liczba wypowiedzi mówiących o ruchu ludzkim ujawniona w grupie rodziców chorych dzieci może świadczyć o mniejszej dojrzałości psychicznej tych osób, co łączy się z mniej wyraźiście ukształtowaną rolą prototypową. Pewne swoiste cechy tych wypowiedzi, można ponadto interpretować jako oznakę trudności w ekspresji tej roli. Współwystępowanie wypowiedzi „ruchowych” z wypowiedziami „światłocieniowymi”, traktowanymi jako wyraz lęku, nie zawsze było zgodne z oczekiwaniami, co należy uznać za przesłankę do zastanowienia się nad psychologicznym znaczeniem tych wypowiedzi i ewentualnego powrotu do oryginalnych poglądów Rorschacha.

Konkluzje: Wyniki badania sugerują mniejszą dojrzałość rodziców chorych dzieci, przejawiającą się słabiej ukształtowaną rolą prototypową i pewnymi trudnościami w ekspresji tej roli. Na podstawie analizy współwystępowania wypowiedzi mówiących o ruchu i wypowiedzi uwzględniających zaznaczony na plamach światłocień można wnosić o potrzebie nowej interpretacji psychologicznej tych wypowiedzi.

Słowa kluczowe: test Rorschacha, schizofrenia, rola prototypowa, endofenotyp

\section{Introduction}

Justification for research devoted to parents of children suffering from schizophrenia is found, among other sources, in the rich body of literature on the subject. In their 1975 book, Steven Hirsch and Julian P. Leff wrote about a mass of contradictory results[1], and I believe that their statement remains valid to this day. In this situation, I decided not to perform a systematic review of the literature, since it would require a separate study; instead, I will offer several selective remarks that seem to be the most relevant for sketching the context of the analyses presented in this paper. Lyman C. Wynne and Margaret Thaler Singer[2] described disorders that affect thinking and communication between the members of families with a child suffering from schizophrenia, and they rank among the most often cited authors. Less often cited ones include the already mentioned Hirsch and Leff, who tried to repeat the study conducted by their colleagues and offered a few critical comments. They demonstrated that, despite the undeniable specificity of responses in the group of parents of schizophrenic children (e.g. the "pressure to speak" observed in fathers of schizophrenic children, which translates into the number of words uttered) - thinking and communication disorders were not found in one-third of these parents, while the similar disorders occurred in around onethird of parents of neurotic children[1]. Communication disorders and abnormalities in the functioning of families with a child suffering from schizophrenia are stressed especially by psychotherapists and clinicians, mainly based on their personal experience of work with these families, e.g. Yryö O. Alanen[3], Albert E. Scheflen[4], Helm
Stierlin, Mary Selvini Palazzoli[3]. The second source of knowledge are empirical studies, case analyses, and even experiments, such as the studies by Carmen Gracia Alba[5] or Krystyna Drat-Ruszczak[6,7]. There are quite a number of Polish studies[8-19]. It can be said that one of the lasting achievements of research on families with a person suffering from schizophrenia is the finding that the cognitive disorders found in schizophrenic individuals occur also in their first-degree relatives, though less intensely. This phenomenon has been associated with the concept of endophenotype. Endophenotype refers to certain clinical or neurobiological characteristics, genetically conditioned, which occur in ill people and, in a more subtle form, in their healthy relatives[20]. Martin Brüne and Gregor Juckel[21] note that the occurrence of these characteristics in healthy relatives does not occur in all cases but should occur more frequently than in the broader healthy population. These characteristics are not necessarily specific to schizophrenia, either - especially, I believe, if they are defined in purely psychological terms. Already Wynne and Singer understood these characteristics as a kind of continuum corresponding to various nosological units. It can be assumed that the existence of endophenotype in the case of fairly narrowly defined cognitive functions in families of individuals suffering from schizophrenia has been empirically proven. Cognitive abilities understood in a broader sense, in the context of social functioning, have not been so thoroughly researched, but they are investigated more and more often[22, 23]. One of the questions I intend to address in the present paper is precisely the question of whether it is legitimate to speak of endophenotype with reference 
to social skills, insofar as conclusions can be drawn about them based on examination using Hermann Rorschach's test. The cognitive disorders that it is possible to detect using the Rorschach test should be understood broadly. The interpretation of inkblots (significantly marked by connotative meanings, evoking emotions) engages both cognitive processes and emotions of the person being examined. It can be said that certain types of responses reflect cognitive processes to a greater degree, while others are more strongly associated with emotions; however, we are never able to make an unambiguous distinction on this issue.

Let me briefly present the result of my previous research conducted with the Rorschach test and concerning a group of parents who had one child suffering from schizophrenia compared to a group of parents who had only healthy children. It turned out that the parents of schizophrenic children had significantly higher values of the Schizophrenia Index (SCZI). The SCZI was developed by John Exner in order to differentiate schizophrenic disorders from the norm or from other psychotic disorders. What is interesting, is that SCZI values differentiated the two groups of parents more clearly than they differentiated the group of their children (patients with schizophrenia in remission and the group of healthy subjects)[24, 25]. Differences between the two groups of mothers were clearer than those between the two groups of fathers. With time, Exner abandoned propagating SCZI as an index of schizophrenia and replaced it with the Perceptual-Thinking Index (PTI). I analyzed the same group of parents by computing the PTI, and I found that parents of a schizophrenic child had higher PTI values compared to parents of healthy children. This means the situation was the same as in the previous study: differences occurred mainly in the case of mothers, whereas fathers of schizophrenic children did not differ significantly from fathers of healthy children[26]. Schizophrenic children did not differ in terms of the PTI from healthy children[27]. Thus, the same pattern manifested itself again: they were parents of schizophrenic children and parents of healthy children who differed to a greater extent than schizophrenic children differed from their healthy peers. The level of the characteristics of responses that are believed to be negative, though not always specific to pathology, was higher in parents than in their schizophrenic biological children. It can be said that the features of responses that were meant to differentiate schizophrenic and healthy individuals differentiated two groups of people who were actually healthy. This suggests that we are in fact dealing with the concept of endophenotype reversed. Already Wynne and Singer[8] found similar relationships in the case of communication disorders: these disorders were more distinct in parents than in their schizophrenic children. Further analyses of Rorschach test responses revealed that fathers of schizophrenic children exhibited a sense of alienation and, consequently, lower social skills as well as worse adjustment[2, 23]. Still another study showed that parents of schizophrenic children more often used symbolic and abstract concepts, and that this tendency was more marked in mothers. In some cases, this way of thinking could be perceived as a tendency to engage in prelogical thinking[28]. I observed the already mentioned "pressure to speak" - reported by Hirsch and Leff - in both fathers and mothers of schizophrenic children. Loquacity was associated with striving to make responses more precise, to comment on them, and to speak about one's own impressions. However, I did not make a statistical comparison that could either confirm or challenge the findings reported by Hirsch and Leff (more frequent responses of this kind in fathers of schizophrenic children compared to mothers of schizophrenic children and compared to parents of healthy children).

The aim of the present paper is to analyze the movement responses collected from a group of parents who had a child suffering from schizophrenia and those collected from a group of parents who had only healthy children. The perception of movement in inkblots reflects the dynamics of the psyche and is one of the key aspects in the interpretation of test results. Any abnormalities in the number, contents, or formal features of this kind of responses may attest to psychological immaturity or even pathology. Nearly all authors writing about the Rorschach test attribute social significance to human movement responses $(M)$, particularly when these responses are connected with certain abnormalities[29-35]. Exner [34] included $M$ responses not adequately reflecting the shape of the inkblots $(M-)$ in the Schizophrenia Index as well as in the Perceptual-Thinking Index. What is usually believed to be particularly important is the subjects' response to Plate III of the test. The inkblots visible on that plate impose an image of human figures in motion on the viewer. When the subject cannot see them or sees them in a distorted way, he or she thereby reveals serious psychological problems[36].

In the present study I rely on the conception of movement developed by Zygmunt Piotrowski in his Perceptanalysis[32]. According to this author, $M$ responses speak of the subjects' deep and most individual tendencies. These tendencies define their life goals, attitude towards life, and attitude towards themselves. It can be said that seeing a human figure in motion reflects the core of personality. Piotrowski refers to it as the model role or the prototypal role which shapes a person's entire life. The prototypal role does not have to be fully conscious, but individuals giving a sufficient number of appropriate 
$M$ responses are capable of effective self-control and delayed gratification; these individuals also have better insight into other people and into themselves. Animal movement responses $(F M)$ or inanimate movement responses $(m)$ reveal tendencies less strongly integrated with personality as a whole, often unconscious ones and related mainly to the sphere of drives.

Piotrowski distinguished three types of movement: extensor, flexor, and blocked. He also distinguished movement expressed only in the form of posture, corresponding to each of these types. The type he considered to be the most desirable is extensor movement, which he associated with spontaneity and assertiveness. Flexor movement, according to this author, may attest to an attitude of submissiveness, or it may be a sign of frustration and a sense of having been defeated. The least desirable type is blocked movement, unproductive and thwarting its outcomes. The type of movement that Piotrowski evaluated particularly negatively is movement expressed in posture, which he associated with mistrust, caution, and reluctance to engage in active and frank relations with people. In Perceptanalysis he also distinguished complex movement, in which various and often opposing tendencies manifest themselves; this type of movement, therefore, speaks of internal conflicts.

In view of numerous reported abnormalities in the communication and emotional climate in families of individuals suffering from schizophrenia, and in view of abundant data concerning mental dysfunctions in the parents of these individuals, it is reasonable to suspect either that the prototypal role in parents of individuals with schizophrenia is insufficiently formed as a result of developmental failures and psychological immaturity, or that parents of schizophrenic individuals encounter difficulties in the free expression of their prototypal role, caused by stress. What should therefore be expected, is a smaller number of $M$ responses, the failure of these responses to reflect the presented inkblots and their certain specific characteristics that are supposed to attest to emotional inhibition and psychological problems, as well as a larger number of blocked-movement, flexormovement, or posture-movement responses. According to Piotrowski, the quality and number of $M$ responses do not change quickly and remain relatively stable over a person's lifetime, but I must admit it cannot be excluded that the possible abnormalities found in $M$ responses merely stem from stress connected with the child's mental illness.

\section{Material and methods}

I tested 31 couples of parents who had a child suffering from paranoid schizophrenia and one mother with a schizophrenic daughter - the father did not participate in the study for unforeseen reasons. The mothers' mean age was 48.2 years and the fathers' mean age was 51.4 years. The dominant group among the fathers (52\%) were subjects with higher education; $26 \%$ of the fathers had secondary education, $12 \%$ had vocational education, and $10 \%$ had elementary education. The largest group among the mothers had secondary education (47\%); $38 \%$ had higher or post-secondary education, $9 \%$ had vocational education, and $6 \%$ had elementary education.

The control group was 21 couples of parents who had healthy children. The mean age was 45.7 years in the case of the mothers and 47.5 years in the case of the fathers. The dominant group among the fathers (48\%) were subjects with secondary education; $33 \%$ of the fathers had higher education, and 19\% had vocational education. In the group of mothers of healthy children it was also secondary education that dominated (52\%), followed by higher education (20\%); $19 \%$ of the mothers had vocational education. On the whole, parents of healthy children were slightly younger and slightly less welleducated than parents of schizophrenic children. The "schizophrenic" families mostly came from relatively big cities (53\%), while the "healthy" families came from both relatively big cities (43\%) and small towns (also 43\%). Rural background was reported by $18 \%$ of "schizophrenic" families and $14 \%$ of "healthy" families.

I conducted the study personally, using the Rorschach projective test. I tested parents of children suffering from paranoid schizophrenia (as defined in DSM-IV) in the final phase of their children's treatment, since that phase involved a somewhat lower level of stress in all family members. The testing took place on the premises of the Psychiatric Clinic of the Medical University in Lublin, in a psychologist's office. As regards parents who did not have a mentally ill child, I recruited them from among the staff of the Psychiatric Clinic and the personnel of the health care center in Lubartów; in the latter case, I performed the test in the psychologist's office at the Mental Health Outpatients' Center. This way of organizing work made it possible for me to know which of the two main study groups a particular person belonged to. All participants consented to be examined; I informed all of them about the anonymous character and purely theoretical purpose of the study. I also explained to the parents who had a schizophrenic child that participation in the study would not affect their child's treatment in any way but could contribute to a better understanding of the disease the child was suffering from.

In the analysis of responses collected during the study I took into account the number of all responses (disproportions could affect the observations) Next, I considered the number of human movement responses $(M)$, the number of animal movement responses $(F M)$, and the number of inanimate movement responses $(\mathrm{m})$. 
All these figures were considered globally and separately for particular plates of the Rorschach test. I combined the above types of movement responses with movement qualities: extensor movement, flexor movement, blocked movement, extensor-posture movement, flexor-posture movement, blocked-posture movement, and complex movement. The next dependent variable was the number of movements of all qualities, considered globally (given in the entire test). I treated all the variables thus distinguished as reflecting the specificity of the form of prototypal role.

I tested the following variables as potentially associated with difficulties in (or ease of) prototypal role expression: $M$ not adequately reflecting the shape of the inkblot $(M-), M$ related to a part of the human body, $M$ related to the inkblot as a whole $(M W), M$ related to a large and/or well-defined part of the inkblot $(M D)$, M related to a small or untypically defined part of the inkblot $(M D d)$, $M$ without reference to the form of the inkblot (formless $M$ ), quasi-human $M, M$ occurring in a positive emotional context $(M C O P$ ), and $M$ saturated with aggressive emotions $(M A G)$. I also considered responses that reported movement and at the same time used shading or color in the interpretation of inkblots.

All the variables distinguished were the same variables that I had considered when comparing the groups of biological children of the tested couples of parents: schizophrenic and healthy children. In the present study I use the system of response interpretation developed by Piotrowski. The $M$ COP and $M A G$ categories are borrowed from Exner's system; Piotrowski did not use such categories, though he did take into account the emotional context of responses. Apart from the content of responses themselves, shading and color added to the perceived movement reveal the emotional tinge of particular observations. It can be assumed that what plays a special role in the expression of the prototypal role is anxiety. I therefore posed a question about the relationship between movement responses and shading responses. I treated the number of the latter, given in the entire test - regardless of whether or not they were combined with movement responses - as a measure of anxiety, in accordance with the commonly adopted principle. I did not use weighted values of these responses, since throughout the analysis I employed the frequencies of specific response types without considering the relations between response categories.

\section{Results}

I estimated the shape of distribution of the variables based on the Kolmogorov-Smirnov test, whose results constituted the point of departure in the selection of the test for comparisons that were meant to show intergroup differences. When testing for intergroup differences in terms of the variables whose distributions coincided with normal distribution, I relied on parametric Student's t-test. To analyze the significance of intergroup differences in terms of the variables whose distributions significantly differed from normal distribution, I employed the nonparametric Mann-Whitney $U$ test. To assess the relations between shading (chiaroscuro) responses and particular types of movement responses, I used Pearson's $r$ (when the variables had a normal distribution) or Spearman's rho (when the distribution of the variables diverged from normal distribution).

The first thing to do was to check if the groups of participants differed in the total number of responses given in the whole test, since that number may indirectly affect the occurrence of various types of observations. The relevant data are presented in Table 1.

Table 1. Mean number of responses, standard deviations, and the significance of differences between the groups of subjects

\begin{tabular}{|c|c|c|c|c|c|}
\hline Group & Mean & $\begin{array}{l}\text { Standard } \\
\text { deviation }\end{array}$ & $\begin{array}{l}\text { Mann- } \\
\text { Whitney } U\end{array}$ & $z$ & Significance \\
\hline $\begin{array}{l}\text { Parents of healthy } \\
\text { children } N=42\end{array}$ & 26.43 & 12.114 & \multirow{2}{*}{1143.500} & \multirow{2}{*}{-1.175} & \multirow{2}{*}{.240} \\
\hline $\begin{array}{l}\text { Parents of schizophrenic } \\
\text { children } N=63\end{array}$ & 27.71 & 11.639 & & & \\
\hline $\begin{array}{l}\text { Mothers of healthy } \\
\text { children } N=21\end{array}$ & 31.05 & 15.253 & \multirow{2}{*}{292.500} & \multirow{2}{*}{-0.792} & \multirow{2}{*}{.429} \\
\hline $\begin{array}{l}\text { Mothers of schizophrenic } \\
\text { children } N=32\end{array}$ & 27.88 & 13.312 & & & \\
\hline $\begin{array}{l}\text { Fathers of healthy } \\
\text { children } N=21\end{array}$ & 21.81 & 4.833 & \multirow{2}{*}{177.500} & \multirow{2}{*}{-2.768} & \multirow{2}{*}{$.006^{*}$} \\
\hline $\begin{array}{l}\text { Fathers of schizophrenic } \\
\text { children } N=31\end{array}$ & 27.55 & 9.838 & & & \\
\hline
\end{tabular}

$* \mathrm{p} \leq .01$ 
As we can see from the data in Table 1., the parents of children with schizophrenia did not give a lower number of responses than the parents of healthy children; mothers of schizophrenic children did not differ in this respect from mothers of healthy children, either. The fathers of schizophrenic and healthy children did differ, however; it was the latter who generated significantly fewer responses in the whole test.

The group of parents of schizophrenic children differed significantly from the group of parents of healthy children in terms of eight variables, and in the case of two variables the differences were very close to the threshold of significance; this is shown in Table 2.

Table 2. Differences and the significance of differences in terms of selected variables between the group of parents of healthy children and the group of parents of schizophrenic children

\begin{tabular}{|c|c|c|c|c|c|c|c|}
\hline \multirow[t]{2}{*}{ Dependent variable } & \multicolumn{2}{|c|}{$\begin{array}{l}\text { Parents } \\
\text { of healthy } \\
\text { children } N=42\end{array}$} & \multicolumn{2}{|c|}{$\begin{array}{l}\text { Parents of } \\
\text { schizophrenic } \\
\text { children } N=63\end{array}$} & \multirow[t]{2}{*}{$z$} & \multirow[t]{2}{*}{$\begin{array}{l}\text { Mann- } \\
\text { Whitney } U\end{array}$} & \multirow[t]{2}{*}{ Significance } \\
\hline & $M$ & $S D$ & $M$ & $S D$ & & & \\
\hline Number of responses to Plate VI & 2.19 & 1.254 & 1.92 & 1.653 & -1.937 & 1045.000 & .053 \\
\hline $\begin{array}{l}\text { Total number of } M \\
\text { responses in the study }\end{array}$ & 2.79 & 1.907 & 0.35 & 0.925 & -2.073 & 1012.000 & $.038^{*}$ \\
\hline $\begin{array}{l}\text { Number of M responses } \\
\text { to Plate VII }\end{array}$ & 0.31 & 0.468 & 0.15 & 0.358 & -2.004 & 1088.000 & $.045^{*}$ \\
\hline $\begin{array}{l}\text { Number of MW } \\
\text { responses to Plate II }\end{array}$ & 0.17 & 1.129 & 0.07 & 0.309 & -1.952 & 1151.500 & .051 \\
\hline $\begin{array}{l}\text { Number of MW responses } \\
\text { to Plate III }\end{array}$ & 1.21 & 1.523 & 0.72 & 0.710 & -2.369 & 988.000 & $.018^{*}$ \\
\hline $\begin{array}{l}\text { Number of MW responses } \\
\text { to Plate VII }\end{array}$ & 0.05 & 0.216 & 0.00 & 0.000 & -2.947 & 1065.000 & $.003^{* *}$ \\
\hline $\begin{array}{l}\text { Number of MD responses } \\
\text { to Plate IV }\end{array}$ & 0.07 & 0.261 & 0.00 & 0.000 & -2.125 & 1209.000 & $.034^{*}$ \\
\hline $\begin{array}{l}\text { Number of chiaroscuro } \\
\text { M responses }\end{array}$ & 0.57 & 1.039 & 0.23 & 0.643 & -2.052 & 1063.000 & $.031^{*}$ \\
\hline $\begin{array}{l}\text { Number of M responses } \\
\text { with animal contents }\end{array}$ & 0.21 & 0.470 & 0.05 & 0.218 & -2.318 & 1115.500 & $.020^{*}$ \\
\hline $\begin{array}{l}\text { Number of chiaroscuro } \\
\text { responses }\end{array}$ & 4.45 & 3.72 & 6.77 & 4.568 & -3.331 & 817.000 & $.001^{* * *}$ \\
\hline
\end{tabular}

${ }^{*} p \leq .05 ;{ }^{* *} p \leq .005 ;{ }^{* * *} p \leq .001$

M- human movement responses

$M W$ - responses reporting human movement related to the inkblot as a whole

MD - responses reporting human movement related to a large / well-defined part of the inkblot

As shown by the data presented in Table 2., parents of schizophrenic children perceived a human figure in motion $(M)$ significantly less in the whole test (plates I $\mathrm{X}$ ), and they perceived it significantly less often in Plate VII. They also less often associated a human figure in motion with the inkblot on Plate IV as a whole. Parents of schizophrenic children less often saw human movement with shading but shading was significantly more frequently considered with reference to all utterances in the examination. Parents of healthy children significantly more often saw movement typical of the human being but attributed it to animals. Parents of healthy children also gave more responses to Plate VI (though this difference only approached significance).

Mothers of schizophrenic children differed from mothers of healthy children only in terms of two variables. The relevant data are presented in Table 3. 
Table 3. Differences and the significance of differences in terms of selected variables between the group of mothers of healthy children and the group of mothers of schizophrenic children

\begin{tabular}{|c|c|c|c|c|c|c|c|}
\hline \multirow[t]{2}{*}{ Dependent variable } & \multicolumn{2}{|c|}{$\begin{array}{l}\text { Mothers of } \\
\text { healthy children } \\
N=21\end{array}$} & \multicolumn{2}{|c|}{$\begin{array}{l}\text { Mothers of } \\
\text { schizophrenic } \\
\text { children } N=32\end{array}$} & \multirow[t]{2}{*}{$z$} & \multirow[t]{2}{*}{$\begin{array}{l}\text { Mann- } \\
\text { Whitney } U\end{array}$} & \multirow[t]{2}{*}{ Significance } \\
\hline & $M$ & $S D$ & $M$ & $S D$ & & & \\
\hline Number of responses to Plate VI & 2.81 & 1.401 & 2.09 & 1.838 & -2.622 & 198.000 & $.009 *$ \\
\hline $\begin{array}{l}\text { Number of MW responses } \\
\text { to Plate VII }\end{array}$ & 0.29 & 0.463 & 0.03 & 0.180 & -2.602 & 243.000 & $.009 *$ \\
\hline
\end{tabular}

$* p \leq .01$

$M W$ - responses reporting human movement related to the inkblot as a whole

As shown by the data presented in Table 3., mothers of schizophrenic children gave significantly fewer responses to Plate VI as well as fewer $M W$ responses to Table VII.

Many more differences manifested themselves

Table 4. Differences and the significance of differences in terms of selected variables between the group of fathers of healthy children and the group of fathers of schizophrenic children

\begin{tabular}{|c|c|c|c|c|c|c|c|}
\hline \multirow[t]{2}{*}{ Dependent variable } & \multicolumn{2}{|c|}{$\begin{array}{l}\text { Fathers of healthy } \\
\text { children } N=21\end{array}$} & \multicolumn{2}{|c|}{$\begin{array}{l}\text { Fathers of } \\
\text { schizophrenic } \\
\text { children } N=31\end{array}$} & \multirow[t]{2}{*}{$z$} & \multirow{2}{*}{$\begin{array}{l}\text { Mann- } \\
\text { Whitney } \\
U\end{array}$} & \multirow[t]{2}{*}{ Significance } \\
\hline & $M$ & $S D$ & $M$ & $S D$ & & & \\
\hline Number of responses to Plate VIII & 2.10 & 0.831 & 3.26 & 1.548 & -2.944 & 173.000 & $.003^{* *}$ \\
\hline Number of M responses & 1.76 & 0.831 & 1.26 & 0.999 & -2.091 & 221.500 & $.037^{*}$ \\
\hline Number of responses to Plate III & 1.10 & 0.539 & 0.77 & 0.762 & -1.977 & 235.000 & $.048^{*}$ \\
\hline $\begin{array}{l}\text { Number of M responses } \\
\text { to Plate VII }\end{array}$ & 0.38 & 0.498 & 0.10 & 0.301 & -2.438 & 233.000 & $.015^{*}$ \\
\hline $\begin{array}{l}\text { Number of MW responses } \\
\text { to Plate II }\end{array}$ & 0.24 & 0.436 & 0.03 & 0.180 & -2.258 & 258.500 & $.024^{*}$ \\
\hline $\begin{array}{l}\text { Number of MW responses } \\
\text { to Plate III }\end{array}$ & 1.05 & 0.590 & 0.58 & 0.672 & -2.888 & 193.000 & $.004^{* *}$ \\
\hline $\begin{array}{l}\text { Number of flexor } M \\
\text { posture responses }\end{array}$ & 0.24 & 0.539 & 0.00 & 0.000 & -2.503 & 263.500 & $.012^{*}$ \\
\hline $\begin{array}{l}\text { Number of MC responses } \\
\text { associated with color.......... }\end{array}$ & 0.57 & 0.811 & 0.19 & 0.543 & -2.077 & 243.500 & $.038^{*}$ \\
\hline $\begin{array}{l}\text { Number of complex } \\
\text { movement responses }\end{array}$ & 0.00 & 0.000 & 0.16 & 0.374 & -1.917 & 273.000 & .055 \\
\hline
\end{tabular}

${ }^{*} p \leq .05 ;{ }^{* *} p \leq .01$

M- human movement responses

$M W$ - responses reporting human movement related to the inkblot as a whole between the group of fathers of schizophrenic children and the group of fathers of healthy children, as can be seen in Table 4. 
The data presented in Table 4. show that the fathers of schizophrenic children gave more responses to Plate VIII, fewer $M$ responses to Plates III and VII, fewer $M W$ responses to Plates II and III, and no flexor-posture $M$ response whatsoever (in the whole test). In the group of fathers of schizophrenic children there were also fewer $M$ responses associated with color as well as fewer $M$ responses (of all qualities taken together in the whole test). Fathers of schizophrenic children exhibited a tendency to speak of complex movement more often, though the difference only approached significance.

Table 5. contains further comparisons between the group of fathers of schizophrenic children and the group of fathers of healthy children.

Table 5. Differences and the significance of differences in terms of selected variables between the group of fathers of healthy children and the group of fathers of schizophrenic children

\begin{tabular}{|c|c|c|c|c|c|c|}
\hline \multirow[t]{2}{*}{ Dependent variable } & \multicolumn{2}{|c|}{$\begin{array}{l}\text { Fathers of healthy } \\
\text { children } N=21\end{array}$} & \multicolumn{2}{|c|}{$\begin{array}{l}\text { Fathers of schizophrenic } \\
\text { children } N=31\end{array}$} & \multirow[t]{2}{*}{ Test + } & \multirow[t]{2}{*}{ Significance } \\
\hline & $M$ & $S D$ & $M$ & $S D$ & & \\
\hline Number of responses to Plate $X$ & 2.67 & 1.390 & 3.87 & 2.078 & 2.324 & $.024^{*}$ \\
\hline Number of MW responses & 1.62 & 1.071 & 0.90 & 1.136 & 2.281 & $.027^{*}$ \\
\hline Number of "chiaroscuro" responses & 3.24 & 2.022 & 6.19 & 3.572 & 3.795 & $.000^{* *}$ \\
\hline
\end{tabular}

${ }^{*} p \leq .05 ;{ }^{* *} p \leq .001$

$M W$ - responses reporting human movement related to the inkblot as a whole

As we can see based on the data presented in Table 5., fathers of schizophrenic children gave more responses to Plate $\mathrm{X}$ and very often used shading in their interpretations of inkblots. The number of MW responses given in the whole test was significantly lower in the group of fathers of schizophrenic children than in the group of fathers of healthy children.

Further tables contain data showing the cooccurrence of various movement qualities with shading responses (anxiety).

Tables 6. and 7. contain information concerning the whole sample.

Table 6. Pearson's r correlations between the "chiaroscuro" variable and movement quality variables in the group of all parents $(N=105)$

\begin{tabular}{|l|l|l|}
\hline $\begin{array}{l}\text { Movement quality } \\
\text { variables }\end{array}$ & $\begin{array}{l}\text { Pearson's } r \\
\text { coefficient }\end{array}$ & Significance \\
\hline $\begin{array}{l}\text { All extensor } \\
\text { movement responses }\end{array}$ & $.582^{* * *}$ & .000 \\
\hline $\begin{array}{l}\text { All flexor movement } \\
\text { responses }\end{array}$ & $.244^{*}$ & .012 \\
\hline
\end{tabular}

$* p \leq .05 ; * * * p \leq .001$

The data presented in Table 6. show that all extensor and flexor movements co-occurred with shading responses.

Table 7. presents relationships between particular movement qualities and shading responses.
Table 7. The values of Spearman's rho between the "chiaroscuro" variable and movement quality variables in the group of all parents $(N=105)$

\begin{tabular}{|l|l|l|}
\hline $\begin{array}{l}\text { Movement quality } \\
\text { variables }\end{array}$ & $\begin{array}{l}\text { Spearman's } \\
\text { rho }\end{array}$ & Significance \\
\hline $\begin{array}{l}\text { All blocked movement } \\
\text { responses }\end{array}$ & .84 & .393 \\
\hline $\begin{array}{l}\text { All blocked movement } \\
\text { responses }\end{array}$ & .114 & .246 \\
\hline $\begin{array}{l}\text { All flexor posture } \\
\text { responses }\end{array}$ & $.280^{* *}$ & .004 \\
\hline $\begin{array}{l}\text { All blocked posture } \\
\text { responses }\end{array}$ & .100 & .308 \\
\hline $\begin{array}{l}\text { All complex movement } \\
\text { responses }\end{array}$ & $.326^{* *}$ & .001 \\
\hline $\begin{array}{l}\text { All movement and } \\
\text { posture responses } \\
\text { (all qualities) }\end{array}$ & $.303^{* *}$ & .002 \\
\hline
\end{tabular}

$* * p \leq .01$

As can be seen based on the data presented in Table 7., all flexor-posture responses, complex movement responses, and responses concerning all movement qualities taken together, significantly co-occurred with shading responses.

Table 8. presents the relationships between movement qualities and shading that were found in the group of parents of schizophrenic children, both fathers and mothers. 
Table 8. Pearson's $r$ correlations in the group of parents of schizophrenic children ( $N=63)$ between the "chiaroscuro" variable and movement quality variables

\begin{tabular}{|l|l|l|}
\hline $\begin{array}{l}\text { Movement quality } \\
\text { variables }\end{array}$ & $\begin{array}{l}\text { Pearson's } r \\
\text { coefficient }\end{array}$ & Significance \\
\hline $\begin{array}{l}\text { All extensor } \\
\text { movement responses }\end{array}$ & $.691^{* * *}$ & .000 \\
\hline $\begin{array}{l}\text { All flexor movement } \\
\text { responses }\end{array}$ & .179 & .160 \\
\hline
\end{tabular}

$* * * p \leq .001$

Table 8. shows that there was highly significant relation between the shading variable and extensor movements as well as complex movements.

Table 9. presents the remaining correlations concerning the parents of schizophrenic children - both fathers and mothers.

Table 9. The values of Spearman's rho between the "chiaroscuro" variable and movement quality variables in the group of parents of schizophrenic children $(N=63)$

\begin{tabular}{|l|l|l|}
\hline $\begin{array}{l}\text { Movement quality } \\
\text { variables }\end{array}$ & $\begin{array}{l}\text { Spearman's } \\
\text { rho }\end{array}$ & significance \\
\hline $\begin{array}{l}\text { All blocked movement } \\
\text { responses }\end{array}$ & .175 & .169 \\
\hline $\begin{array}{l}\text { All extensor posture } \\
\text { responses }\end{array}$ & .203 & .111 \\
\hline $\begin{array}{l}\text { All flexor posture } \\
\text { responses }\end{array}$ & $.270^{*}$ & .032 \\
\hline $\begin{array}{l}\text { All blocked posture } \\
\text { responses }\end{array}$ & .100 & .437 \\
\hline $\begin{array}{l}\text { All complex movement } \\
\text { responses }\end{array}$ & $.250^{*}$ & .048 \\
\hline $\begin{array}{l}\text { All movement and } \\
\text { posture responses } \\
\text { (all qualities) }\end{array}$ & $.418^{* *}$ & .001 \\
\hline
\end{tabular}

${ }^{*} p \leq .05 ;{ }^{* *} p \leq .01$;

The values of Spearman's rho coefficients presented in Table 9. reveal a significant relationship between shading responses and flexor posture responses as well as responses concerning complex movement and all movement qualities.

Spearman's rho coefficients for the group of parents of healthy children are presented in Table 10.

Table 10. The values of Spearman's rho between the "chiaroscuro" variable and movement quality variables in the group of parents of normal children $(N=42)$

\begin{tabular}{|l|l|l|}
\hline $\begin{array}{l}\text { Movement quality } \\
\text { variables }\end{array}$ & $\begin{array}{l}\text { Spearman's } \\
\text { rho }\end{array}$ & significance \\
\hline $\begin{array}{l}\text { All extensor movement } \\
\text { responses }\end{array}$ & $.512^{* *}$ & .001 \\
\hline $\begin{array}{l}\text { All flexor movement } \\
\text { responses }\end{array}$ & -.075 & .637 \\
\hline $\begin{array}{l}\text { All blocked movement } \\
\text { responses }\end{array}$ & .039 & .808 \\
\hline $\begin{array}{l}\text { All extensor posture } \\
\text { responses }\end{array}$ & .133 & .401 \\
\hline $\begin{array}{l}\text { All flexor posture } \\
\text { responses }\end{array}$ & .264 & .091 \\
\hline $\begin{array}{l}\text { All blocked posture } \\
\text { responses }\end{array}$ & .126 & .001 \\
\hline $\begin{array}{l}\text { All complex movement } \\
\text { responses }\end{array}$ & $.477^{* *}$ & .264 \\
\hline $\begin{array}{l}\text { All movement and } \\
\text { posture responses } \\
\text { (all qualities) }\end{array}$ & .176 & .028 \\
\hline
\end{tabular}

** $p \leq .01 ;$

The data in Table 10. show that in the group of parents of healthy children there was a significant relationship between shading responses and complex movement responses as well as responses concerning extensor movement responses.

Correlations for the group of all fathers are presented in Table 11.

Table 11. The values of Spearman's rho between the "chiaroscuro" variable and movement quality variables in the group of all fathers $(N=52)$

\begin{tabular}{|l|l|l|}
\hline $\begin{array}{l}\text { Movement quality } \\
\text { variables }\end{array}$ & $\begin{array}{l}\text { Spearman's } \\
\text { rho }\end{array}$ & significance \\
\hline $\begin{array}{l}\text { All extensor movement } \\
\text { responses }\end{array}$ & $.395^{* *}$ & .004 \\
\hline $\begin{array}{l}\text { All flexor movement } \\
\text { responses }\end{array}$ & -.042 & .769 \\
\hline $\begin{array}{l}\text { All blocked movement } \\
\text { responses }\end{array}$ & -.044 & .754 \\
\hline $\begin{array}{l}\text { All extensor posture } \\
\text { responses }\end{array}$ & .031 & .828 \\
\hline $\begin{array}{l}\text { All flexor posture } \\
\text { responses }\end{array}$ & .257 & .066 \\
\hline $\begin{array}{l}\text { All blocked posture } \\
\text { responses }\end{array}$ & .089 & .529 \\
\hline $\begin{array}{l}\text { All complex movement } \\
\text { responses }\end{array}$ & $.287^{*}$ & .039 \\
\hline $\begin{array}{l}\text { All movement and posture } \\
\text { responses (all qualities) }\end{array}$ & .181 & .199 \\
\hline
\end{tabular}

${ }^{*} p \leq .05 ;{ }^{* *} p \leq .01$; 
In the group of all fathers, two significant relationships manifested themselves: between shading responses and extensor as well as complex movement responses.

The correlation coefficients for the group of all mothers are presented in Table 12.

Table 12. Pearson's $r$ correlations in the group of all mothers $(N=53)$ between the "chiaroscuro" variable and all extensor movement responses

\begin{tabular}{|l|l|l|}
\hline $\begin{array}{l}\text { Movement quality } \\
\text { variable }\end{array}$ & $\begin{array}{l}\text { Pearson's } r \\
\text { coefficient }\end{array}$ & Significance \\
\hline $\begin{array}{l}\text { All extensor } \\
\text { movement responses }\end{array}$ & $.670^{* * *}$ & .000 \\
\hline
\end{tabular}

*** $p \leq .01$;

In the group of all mothers there was significant correlation between shading responses and extensor movement responses.

Table 13. presents the remaining correlations in the group of all mothers

Table 13. The values of Spearman's rho between the "chiaroscuro" variable and movement quality variables in the group of all mothers $(N=53)$

\begin{tabular}{|l|l|l|}
\hline $\begin{array}{l}\text { Movement quality } \\
\text { variables }\end{array}$ & Spearman's rho & Significance \\
\hline $\begin{array}{l}\text { All flexor movement } \\
\text { responses }\end{array}$ & .265 & .055 \\
\hline $\begin{array}{l}\text { All blocked movement } \\
\text { responses }\end{array}$ & .159 & .256 \\
\hline $\begin{array}{l}\text { All extensor posture } \\
\text { responses }\end{array}$ & .231 & .095 \\
\hline $\begin{array}{l}\text { All flexor posture } \\
\text { responses }\end{array}$ & .263 & .057 \\
\hline $\begin{array}{l}\text { All blocked posture } \\
\text { responses }\end{array}$ & .138 & .323 \\
\hline $\begin{array}{l}\text { All complex } \\
\text { movement responses }\end{array}$ & $.324^{*}$ & .018 \\
\hline $\begin{array}{l}\text { All movement and } \\
\text { posture responses } \\
\text { (all qualities) }\end{array}$ & $.440^{* *}$ & .001 \\
\hline
\end{tabular}

${ }^{*} p \leq .05$; $^{*} p \leq .01$

As can be seen based on the data presented in Table 13, all complex movement responses and all movement responses (all qualities) significantly co-occurred with shading responses.

\section{Discussion}

Parents who have a child suffering from schizophrenia perceived a human figure in motion significantly less often than parents who have only healthy children. This is a very important aspect of responding to inkblots. With Piotrowski, we can say that parents of schizophrenic children did not manifest their individuality as clearly as did parents of healthy children, what means that their prototypal role was probably not so strong model giving shape to the entire life as it was in the parents of healthy children. The lower number of $M$ responses may also be associated with lower maturity and psychological integration and with slightly weaker selfcontrol. What is more, the expression of the less numerous $M$ responses was frequently hindered. This manifested itself, among other things, in the smaller number of $M$ responses relating to the whole inkblot visible on the plate. $M W$ responses were less frequent especially in the case of Plates II, III, and VII, and it is on these particular plates that it is not difficult to see a human figure. In the case of Plate II it is enough to include the upper red blots in the observation, interpreting them, for instance, as hoods. In the case of Plate VII, seeing women's or children's heads is so frequent that responses to that effect have been given the status of popular responses. Linking the perceived heads with the rest of the inkblot is not difficult here, either, and it even suggests itself. Parents of schizophrenic children gave fewer $M$ and $M W$ responses to this plate; it can be said that in this way they showed a serious deficit in the kind of responding that is generally typical of examined individuals.

A very important result was the smaller number of MW responses to Plate III. In Piotrowski's interpretative system perceiving people in motion in the dark inkblot is treated as an $M W$ response, and it is not necessary in this case to include the little red blots in the observation for the response to qualify as $M W$. Piotrowski was guided by the principles of Gestalt psychology: an indeed, the dark inkblot is a figure so good that it virtually forces the viewer to perceive human figures. Precisely for this reason perceiving people in this inkblot in a typical way is a popular reaction and a key one in interpretation. We can even say that this is the only response in the entire test which is not treated as free but as a kind of norm. Any abnormalities in this response are therefore highly meaningful and may attest to deficits in the development and expression of the prototypal role. Seeing people in an untypical way in Plate III is often rated as a response not adequately reflecting the shape of the inkblot $(M-)$. Parents of schizophrenic children gave more $M-$ responses, though the difference did not reach the level of significance (for this reason I have not included these data in Table 2.; parents of healthy children: $M=.07, \mathrm{SD}=.261$, parents of schizophrenic children: $M=.35, \mathrm{SD}=.9225, \mathrm{z}$ $=-1.776$, Mann-Whitney $U=1158.000$, significance $=$ .076). It should be checked if wrong interpretations of 
human figures on Plate III resulted in a higher number of $M$ - responses in the group of parents of schizophrenic children.

Parents of schizophrenic children more often used shading in their interpretations of inkblots, which means the level of anxiety was significantly higher in their case than in parents of healthy children. It is not easy in this context to explain the fact that the perception of human movement combined with the inclusion of shading was more frequent in parents of healthy children. Perhaps for parents of schizophrenic children the perception of a human figure in motion was so engaging that the remaining energy was not enough to discern the nuances in the saturation of gray color. As we will see further, fathers of schizophrenic children combined a human figure in motion with the use of color less often than fathers of healthy children; this (as well as the noninclusion of shading in the perception of human figures in motion) may, to some degree, attest to the fact that the human movement responses given by fathers of schizophrenic children were more plain and less complex. Likewise, it is difficult to find a clear rationale for the less frequent $M D$ responses to Plate IV (in the group of parents of schizophrenic children) - in other words, to the less frequent perception of a human figure in motion in a large and/or well-defined part of the inkblot. In this plate it is relatively easy to see an entire human or quasi-human figure in the whole inkblot, but it is a lot more difficult to see a human figure in a part of the inkblot. Explaining the obtained results would require an in-depth analysis of responses given to Plate IV, which is outside the scope of this paper; such an analysis would be very interesting, however - especially because the emotional tinge of the inkblot on Plate IV is considered to be one of the most negative in the whole test. The lower number of responses to Plate VI in the group of parents of schizophrenic children can be seen as stemming from the fact that this plate fairly often evokes associations connected with the sexual sphere; it should not be forgotten, however, that the inkblot visible on this plate is one of the most difficult to interpret. It is interesting that parents of healthy children significantly more often attributed movement typical of human figures to animals. Piotrowski associates this kind of responses with an idealistic attitude towards the world, what becomes a source of disappointments and a loss of faith or trust in people. The bitterness connected with the situation can be deep and painful and can lead to depressive states, but it can also give rise to cynicism and opportunism.

The comparison of results between mothers of schizophrenic and healthy children as well as between fathers of schizophrenic and healthy children shows that differences occurred mainly in the group of fathers.
Mothers differed only in the number of responses to Plate VI and in the number of $M W$ responses to Plate VII. I am not going to discuss these differences here because I have already discussed them when comparing all parents of schizophrenic and healthy children, especially as the direction of differences was the same. It can be said that it is mainly fathers of schizophrenic children who turned out to be distinct in terms of the perception of human movement. First of all, they were fathers of schizophrenic children who less often saw a human figure in motion $(M)$ when the whole test was taken into account; they also less often gave this kind of response to Plates III and VII - the plates on which, as I have mentioned before, it is particularly easy to discern a moving person. Also, fathers of schizophrenic children significantly less often saw people in motion in the whole of inkblots visible on Plates II and III, and the level of anxiety measured by the number of shading responses was very significantly higher in their case than in the case of fathers of healthy children. Fathers of schizophrenic children less often combined the perception of human figure in motion with the inclusion of color $(M C)$, which, as I have pointed out, may attest to more limited experience of this movement. Fathers of schizophrenic children gave significantly more responses in the whole test, what may be understood as showing that they cooperated with the testing person better and perhaps felt their dependence on the staff treating their children. The higher total number of responses additionally enhances the significance of the lower number of $M$ responses, as fathers of schizophrenic children had more opportunities to see people in motion but, for some reason, they were unable to use them. Fathers of healthy children gave particularly few responses to Plates VIII and X. It is possible to try to explain this as stemming from neurotic emotional difficulties. Plate VIII, as the first multicolored one after a number of dark plates, can be a source of surprise and result in the inability to cope with the emotions stirred by the colors. Plate $\mathrm{X}$ is difficult to interpret, since it can cause a sense of chaos and an excess of associations relating to specific parts of the inkblot accompanied by a shortage of ideas relating to the whole. It can be suspected that fathers of healthy children "resisted" the examination (fewer responses given in the whole test, higher likelihood of cynicism and opportunism) to a greater extent than fathers of schizophrenic children and that they more often reacted emotionally in a way that resembled neurotic reactions.

What is difficult to interpret, is the more frequent human flexor-posture-movement responses in the group of fathers of healthy children; I expected such responses in fathers of schizophrenic children. These results are not consistent with the entire picture of results, if we follow Piotrowski's interpretation of movement qualities. 
I believe that the higher number of complex movement responses in the group of fathers of schizophrenic children can be linked with a higher level of anxiety in the tested individuals and perhaps also with ambivalence. Despite the higher number of flexor-posture-movement responses in the group of fathers of healthy children, it is possible to conclude (taking the entirety of the obtained result into account) that fathers of healthy children showed greater maturity, in the sense that their prototy pal role manifested itself more distinctly and was expressed with greater ease, while their level of anxiety was significantly lower. It should be stressed that they were fathers who differed to a greater degree, not mothers. These conclusions are not frequent in the literature, but the higher specificity of responding in the case of fathers of schizophrenic children has nevertheless been reported by Hirsh and Leff [1]; let me also mention that they were fathers of schizophrenic children who showed a higher sense of isolation and alienation, as well as certain signs of weaker socialization [23]. On the other hand, perceptual and thinking disorders were more distinct in mothers $[25,26]$.

What is particularly important, is the fact that the comparison between parents of schizophrenic children and parents of healthy children revealed those differences that could be expected in the comparison of their schizophrenic and healthy children. The same situation occurred when I analyzed the level of Exner's Schizophrenia Index (SCZI) and Perceptual-Thinking Index (PTI); both indices were constructed to detect pathologies, but it turned out they differentiated healthy rather than schizophrenic individuals [24-27]. This is especially surprising because, considering the concept of endophenotype, we could expect the reverse pattern: clear characteristics rated as pathological in the group of schizophrenic individuals and the same characteristics, though less marked, in their parents. A possible explanation that could be suggested is that the specificities found in the responses given by parents of schizophrenic children stem from their personality traits, while the corresponding specificities found in their children thrive in psychosis in order to recede with the remission of the disease, or may be the nature of the examined features differ from the nature of the features included in the concept of endophenotype.

Different movement qualities distinguished in perceptanalysis are particularly important for the psychological interpretation of Rorschach test results. The most desirable quality is free, extensor and devoid of negative emotional connotations movement. Flexor movement is treated as associated with a feeling of frustration and disappointment as well as with the attitude of yielding to difficulties. Blocked movement suggests the subject's passiveness, the rigidity of his or her thinking processes, and indecision. Piotrowski stresses the negative aspects of this type of movement, since it does not lead to any outcomes but thwarts the very changes it seems to be making. Also unfavorable, according to Piotrowski, is the perception of movement in the form of posture (posture movement), which he sees as attesting to mistrust and reluctance to remain in frank, open relations with other people. Complex movement, which we speak of when one object makes at least two movements different in quality, is interpreted as a sign of ambivalence and internal conflicts. Although the movement qualities listed here are not directly associated with anxiety, Piotrowski admits that anxiety favors the perception of flexor, blocked, and posture movement [32. It is difficult to offer a suggestion regarding the relationship of anxiety with complex movement, especially as I have not found any reports concerning this issue; it can be assumed, however, that this movement - expressing certain internal conflicts - may be associated with anxiety [32]. There are fairly abundant empirical data concerning the occurrence of flexor movement [32, 37]. Exner distinguishes only two movement qualities: active movement and passive movement. Active movement certainly corresponds to Piotrowski's extensor movement, whereas passive movement covers the remaining movement types. Passive movements in Exner's system are seen as less favorable and often included in various indicators of pathology. It can be assumed that the perception of extensor movement is unlikely to co-occur with anxiety.

In the light of the above, what turned out to be a rather unexpected result is the significant positive correlation between anxiety measured by shading responses and the number of all perceived movements, globally considered. It occurred in the whole group, in the group of parents of schizophrenic children, and in the group of all mothers. What is more, the number of all extensor movements which "should not" be associated with anxiety, correlated positively with shading responses in all the groups I examined: in the whole sample, in the group of parents of schizophrenic children, in the group of parents of healthy children, in the group of all mothers, and in the group of all fathers. Unfortunately, in the groups of children, analyzed in the previous study, extensor movement did not correlate with anxiety, but all movement qualities globally considered significantly correlated with anxiety in the group of sons and in the whole sample of children.

As expected, the study revealed the co-occurrence of flexor movement with anxiety in the whole sample (in the group of all mothers this relationship approached significance) and the co-occurrence of anxiety with flexor-posture movements (in the whole sample and in the group of parents of schizophrenic children; in the group of mothers, the relationship between these variables 
approached significance). As the first study showed, such relationships did not occur in the groups of children [38].

A surprising result was the lack of relationship between extensor-posture movement and anxiety. This is because it is hard not to assume the possibility that anxiety is precisely what stops extensor movement, "freezing" it, as it were, and impeding its realization. When analyzing the relations between anxiety and the occurrence of various movement qualities in the children of the tested parental couples of parents, in one case (i.e., in the group of all healthy children) I obtained the contrary, expected results - namely, extensor-posture movement responses correlated significantly positively with shading responses. It is not easy to comment on this inconsistency in the results; it should be taken into account that the groups of children were not large enough, and that, consequently, the results obtained in the analysis of parental groups seem to be more reliable.

The pattern of relationships was consistent in the case of blocked movement and blocked-posture movement - both in the groups of parents and in the groups of their children analyzed in the previous study. I found no significant relationships here (only in the group of healthy children was Spearman's rho close to the significance level). I believe this situation could be explained as stemming from the fact that perhaps blocked movement, as the kind of movement thwarting its outcomes, is not interpreted by the subjects as movement at all - but rather as immobility, maintaining the status quo, and that blocked-posture movement is even less likely to be interpreted as movement. All the remaining movements, even complex ones and those expressed in the form of postures, are probably regarded by the subjects as either movement or potential movement! It would therefore be advisable to reflect on the psychological meanings of blocked movement responses blocked-posture movement responses.

In all the analyzed groups of parents there consistently appeared a significant and highly significant correlation between complex movement and anxiety. In the group of sons, as I have mentioned before, there was an unexpected negative correlation between anxiety and complex movement responses, which, arguably, should be treated as an artefact.

To sum up, the most consistent result was the relationship of all types of movement (including extensor movement) with shading responses; as the specific results are not always consistent, I believe this can be the pattern to focus on. This pattern was prevalent also in the analysis pertaining to groups of children. It should therefore be concluded that anxiety motivates the examined individuals to perceive movement of all qualities, which means that it not only performs an inhibitory role but also acts as a motivating force, promoting the perception of movement. To remain within the framework of perceptanalysis, one could stress this ("additional," as it were) interpretation of shading responses, which links these responses with the richness of personality, with positively understood complexity, and with better insight into oneself and other people; as Piotrowski emphasized, shading responses have a negative meaning only when they dominate over other ways of responding, especially when they inhibit color responses.

The obtained results suggest the need to reconsider the psychological interpretation of movement qualities such as blocked movement and posture movement; perhaps they should be looked at more positively. The results shed some new light on shading responses, too.

In this context, it is worth referring to Rorschach's original views, as Rorschach saw the very essence of movement as involving a conflict between spontaneity and discipline, between impetuousness and movement bound by norms, customs, or culture. As demonstrated by Akavia [39], Rorschach's fascination with movement was in fact a fascination with this particular conflict. The relationship of perceived movement with responses attesting to the experience of anxiety corresponds with the understanding of movement in Rorschach's thought. Movement is a dialectic phenomenon; it is a struggle between two opposing tendencies: tendency towards freedom and tendency towards control [3941]. According to Rorschach, this conflict is a condition of internal creative development (which makes the presence of anxiety understandable), and the analysis of movement perception provides us with an insight into the structure of the tested individual's self [39-41]. Accepting the positive role of movement dialectics also leads to a necessary change in the psychological interpretation of movement expressed in the form of posture.

Finally, it has to be borne in mind that the most interesting and the most unequivocal finding was the difference in the number of utterances concerning human movement between the parents of sick and healthy children. The differences in the movement quality were not significant. The fact worth mentioning is that flexor posture movement was more frequently mentioned by the fathers of healthy children. This, however, is not entirely coherent with Piotrowski's concept of movement. Similarly, the relation between particular movement qualities and anxiety was not always consistent with the original assumptions. Nevertheless, the results confirm the ideas of James P. Choca and Edward D. Rossini who claim that even such basic difference as between active and passive movement - however useful in the clinical assessment - is not confirmed in broader empirical research. At the same time, the sole perception of movement, human movement 
in particular, still remains a very significant variable [42].

\section{Conclusions}

1. The group of parent with a schizophrenic child differed from the group of parents who have only healthy children to a greater degree than the group of their biological schizophrenic children differed from the group of children from control families.

2. Parents of schizophrenic children exhibited a less clearly formed prototypal role and showed fairly numerous signs of difficulties in expressing this role. Differences between fathers of schizophrenic children and fathers of healthy children were larger than the corresponding differences between mothers.
3. Parents of schizophrenic children, especially fathers, showed a higher level of anxiety measured by the number of shading responses.

4. The analysis of co-occurrence of various kinds of movement responses and responses interpreting shading yielded a better insight into the psychological significance of each movement quality perceived in inkblots (what is particularly necessary, is a new perspective on blocked-posture movement and extensor-posture movement). I have pointed out the need to return to Rorschach's original thought, and Rorschach viewed perception as involving a conflict between opposing tendencies: striving for freedom and striving for control.

\section{Wstęp}

Uzasadnieniem dla badania rodziców chorych na schizofrenię dzieci, są między innymi, liczne i niejednoznaczne wyniki dotychczasowych badań dotyczących tej problematyki. Steven Hirsch i Julian P. Leff w swojej książce z 1975 roku piszą o wielu sprzecznych wynikach badań[1] i uważam, że do tej pory stwierdzenie to jest aktualne. W takiej sytuacji nie decyduję się na systematyczny przegląd literatury, wymagałby on bowiem osobnego opracowania; w zamian podam parę wybiórczych uwag, które wydają się najistotniejsze dla naszkicowania kontekstu dla prezentowanych w tej pracy analiz. Lyman C. Wynne i Margaret Thaler Singer[2] opisali zaburzenia myślenia i komunikacji między członkami rodzin z dzieckiem chorym na schizofrenię i są jednymi z najczęściej cytowanych autorów. Rzadziej przywołuje się jednak wspomnianych już Hirscha i Leffa, którzy usiłowali powtórzyć badania swoich kolegów i wysunęli parę krytycznych uwag. Wykazali, że mimo niewątpliwej specyfiki reagowania w grupie rodziców chorych dzieci (np. zaobserwowanej u ojców chorych dzieci „presji do mówienia", która przekłada się na liczbę wypowiedzianych słów) - zaburzeń myślenia i wzajemnej komunikacji nie stwierdza się u jednej trzeciej tych rodziców, podczas gdy podobne zaburzenia występują u około jednej trzeciej rodziców dzieci neurotycznych[1, s.169). Zaburzenia w komunikacji i odmienności w funkcjonowaniu rodzin z chorym na schizofrenię dzieckiem podkreślają zwłaszcza psychoterapeuci i klinicyści, opierając się głównie na osobistych doświadczeniach w pracy z tymi rodzinami, np. Yryö 0. Alanen [3], Albert E. Scheflen [4], Helm Stierlin, Mary Selvini Palazzoli [za 3]. Drugi nurt wiedzy płynie z prac empirycznych, analiz przypadków a nawet przeprowadzonych eksperymentów, np. badania Carmen Graci Alba [5], Krystyny Drat-Ruszczak [6,7]. Niemało jest opracowań polskich [8-19]. Można powiedzieć, że do trwałych zdobyczy w badaniach nad rodzinami z osobą chorą na schizofrenię należy ustalenie, że występujące $u$ tych chorych zaburzenia poznawcze występują także u ich krewnych pierwszego stopnia, choć w mniejszym nasileniu. Zjawisko to związano $\mathrm{z}$ pojęciem endofenotypu. Endofenotyp to pewne cechy kliniczne lub neurobiologiczne, uwarunkowane genetycznie, które występują u osób chorych oraz w subtelniejszej formie u ich zdrowych krewnych[20]. Martin Brüne i Gregor Juckel[21] zaznaczają, że ujawnienie się tych cech u zdrowych krewnych nie musi występować, powinno jednak pojawiać się częściej niż w zdrowej, szerszej populacji. Cechy te nie muszą też być swoiste tylko dla schizofrenii, szczególnie jeśli, jak myślę, zdefiniujemy je w aspekcie czysto psychologicznym. Już Wynne i Singer ujmowali te cechy jako pewne kontinuum przypisane różnym jednostkom nozologicznym. Można przyjąć, że istnienie endofenotypu w odniesieniu do w miarę wąsko zdefiniowanych funkcji poznawczych wrodzinach chorych na schizofrenię zostało udowodnione empirycznie. Zdolności poznawcze ujęte szerzej, w kontekście funkcjonowania społecznego, nie są tak dobrze znane, ani u osób chorych ani u ich krewnych, ale coraz częściej poddawane są badaniu[22, 23]. Jedno z pytań, do którego chcę się przybliżyć w tej pracy to właśnie pytanie o to, czy możemy mówić o endofenotypie w odniesieniu do umiejętności społecznych, o tyle o ile można o nich wnioskować na podstawie badania testem Hermanna Rorschacha. Zaburzenia poznawcze, które można uchwycić w badaniu testem Rorschacha należy rozumieć szeroko. Interpretacja plam atramentowych (o znacznym nacechowaniu znaczeniami konotacyjnymi, budzącymi emocje) angażuje zarówno procesy poznawcze jak i sferę emocjonalną badanej osoby. Możemy mówić, że pewne typy wypowiedzi odzwierciedlają w większym stopniu procesy poznawcze, a inne są bardziej związane z emocjami; ale nigdy nie potrafimy dokonać tu jednoznacznego rozróżnienia. 
Zreferuję pokrótce wyniki dotychczasowych moich badań przeprowadzonych za pomocą testu Rorschacha, a dotyczących grupy rodziców mających dziecko chore na schizofrenię, w porównaniu z wynikami grupy rodziców mających same zdrowe dzieci. Jak się okazało, rodzice chorych dzieci uzyskiwali istotnie wyższe wartości w indeksie schizofrenii (SCZI). Wskaźnik SCZI opracował John Exner, aby różnicować zaburzenia schizofreniczne od normy lub od innych zaburzeń psychotycznych. Interesujące jest to, że wartości SCZI zróżnicowały obie grupy rodziców wyraźniej niż grupę ich dzieci (pacjentów chorych na schizofrenię w stanie remisji i grupę osób zdrowych)[24, 25]. Różnice między obydwiema grupami matek były wyraźniejsze niż między obydwiema grupami ojców. Z czasem Exner wycofał się z propagowania SCZI jako wskaźnika schizofrenii i zastąpił go wskaźnikiem zaburzeń percepcji i myślenia (PTI). Zanalizowałam tę samą grupę rodziców, obliczając wskaźnik PTI i okazało się, że rodzice mający chore dziecko uzyskiwali istotnie wyższe wartości PTI w porównaniu z grupą rodziców zdrowych dzieci. Powtórzyła się więc tu sytuacja z poprzedniego badania: zróżnicowanie dotyczyło głównie matek, podczas gdy ojcowie dzieci chorych i zdrowych nie różnili się od siebie istotnie[26]. Chore i zdrowe dzieci nie różniły się od siebie wskaźnikiem PTI[27]. Znów ukazał się więc ten sam układ: to rodzice dzieci chorych i rodzice dzieci zdrowych, mimo że wszyscy byli osobami zdrowymi, bardziej różnili się od siebie niż ich chore dzieci od swoich zdrowych rówieśników. Nasilenie cech wypowiedzi uważanych za niekorzystne, choć nie zawsze swoistych dla patologii było wyraźniejsze u rodziców niż u ich biologicznych chorych dzieci. Możemy powiedzieć, że te cechy wypowiedzi, które miały zróżnicować ludzi chorych i zdrowych, różnicowały dwie grupy osób w zasadzie zdrowych. Nasuwa się spostrzeżenie, że mamy tu do czynienia niejako z odwróconym pojęciem endofenotypu. Już Wynne i Singer stwierdzili podobne zależności w odniesieniu do zaburzeń komunikacji: zaburzenia te były wyraźniejsze u rodziców niż u ich chorych dzieci[za 8]. Następne analizy wypowiedzi uzyskiwanych w teście Rorschacha wykazały, że ojcowie chorych dzieci ujawnili poczucie wyobcowania i związane z nim mniejsze umiejętności społeczne i gorsze przystosowanie[2, 23]. Inne jeszcze badania pokazały, że rodzice chorych dzieci częściej posługiwali się pojęciami symbolicznymi i abstrakcyjnymi i tendencja ta była z kolei wyraźniejsza u matek. Taki sposób myślenia w niektórych przypadkach można było spostrzegać jako tendencję do myślenia prelogicznego[28]. Wspomniane już przeze mnie twierdzenie Hirscha i Leffa, że ojcowie chorych dzieci wykazują „presję do mówienia”, obserwowałam zarówno u ojców jak i matek chorych dzieci. Wielomówność wiązała się z usiłowaniem precyzowania wypowiedzi, komentowania ich a także $\mathrm{z}$ mówieniem o własnych odczuciach. Nie uczyniłam jednak statystycznego porównania, które mogłoby potwierdzić lub zmienić ustalenia Hirscha i Leffa (częstsze wypowiedzi tego typu u ojców chorych dzieci w porównaniu z matkami chorych dzieci i w porównaniu z rodzicami dzieci zdrowych).

Celem niniejszej pracy jest analiza wypowiedzi „ruchowych” uzyskanych w grupie rodziców mających chore dziecko oraz $w$ grupie rodziców mających tylko zdrowe dzieci. Dostrzeganie ruchu w plamach atramentowych odzwierciedla dynamikę psychiki i jest jednym z kluczowych aspektów w interpretowaniu wyników testu. Wszelkie nieprawidłowości w liczbie tego typu wypowiedzi, w ich treści lub w cechach formalnych, mogą świadczyć o niedojrzałości psychicznej, a nawet o patologii. Wszyscy niemal autorzy zajmujący się testem Rorschacha szczególne znaczenie nadają wypowiedziom mówiącym o spostrzeganiu postaci ludzkiej w ruchu $(M)$, zwłaszcza gdy wiążą się one $\mathrm{z}$ pewnymi nieprawidłościami[29-35]. Exner[34] wprowadza wypowiedzi $M$ nieadekwatne do prezentowanych plam (tzw. $M-$ ) do wskaźnika schizofrenii oraz do wskaźnika zaburzeń percepcji i myślenia. Na ogół uważa się, że szczególnie ważna jest reakcja badanych na tablicę III testu. Plamy widniejące na tej tablicy narzucają patrzącemu obraz postaci ludzkich w ruchu. Gdy badany nie widzi ich lub widzi w sposób zniekształcony, ujawnia tym samym swoje poważne problemy psychologiczne[36].

W niniejszej pracy opieram się na koncepcji ruchu opracowanej przez Zygmunta Piotrowskiego w jego Perceptanalizie[32]. Według tego autora wypowiedzi $M$ mówią o głębokich, najbardziej indywidualnych tendencjach badanego. Tendencje te określają jego cele życiowe, postawę do życia i samego siebie. Można powiedzieć, że widzenie postaci ludzkiej w ruchu odzwierciedla trzon osobowości. Piotrowski nazywa go rolą wzorcową lub rolą prototypową, która nadaje kształt całemu naszemu życiu. Rola prototypowa nie musi być w pełni świadoma, jednak osoby dające dostateczną liczbę prawidłowych wypowiedzi $M$ zdolne są do skuteczniejszej samokontroli i do odraczania nagrody; osoby te również mają lepszy wgląd w innych ludzi i w samego siebie. Wypowiedzi mówiące o ruchu zwierząt $(F M)$ lub o przedmiotach nieożywionych będących w ruchu (m) wskazują na tendencje słabiej zintegrowane z całą osobowością, często nieświadome i związane głównie ze sferą popędową.

Piotrowski wyróżnił trzy rodzaje ruchu: rozmachowy, skulony i niezdecydowany. Każdemu z nich przypisał też ruch wyrażony jedynie w postawie. Za najkorzystniejszy uważał ruch rozmachowy i który łączył ze spontanicznością i asertywnością. Ruch skulony według tego autora może świadczyć o postawie 
uległości lub może być wyrazem frustracji i poczucia bycia pokonanym. Najmniej korzystny jest ruch niezdecydowany jako nieproduktywny i niweczący swoje efekty. Piotrowski szczególnie negatywnie ocenia ruch wyrażony jedynie w postawie łącząc go z nieufnością, ostrożnością, niechęcią do aktywnych, szczerych stosunków z ludźmi. W Perceptanalizie wyróżnia się też ruch złożony, w którym przejawiają się różne, często przeciwstawne tendencje, ten typ ruchu mówi więc o wewnętrznych konfliktach.

Wobec licznych doniesień o nieprawidłowościach w sposobie komunikacji i klimacie emocjonalnym w rodzinach osób chorych na schizofrenię, a także wobec licznych danych o dysfunkcjach psychicznych u rodziców tych chorych, można przypuszczać, że rola prototypowa u rodziców osób chorych na schizofrenię jest albo niedostatecznie wykształcona na skutek niepowodzeń rozwojowych i niedojrzałości psychicznej, albo też rodzice osób chorych napotykają trudności w swobodnej ekspresji swojej roli prototypowej spowodowane stresem. Należy się więc spodziewać mniejszej liczby wypowiedzi $M$, nieadekwatności tych wypowiedzi w stosunku do prezentowanych badanym plam i pewnych ich specyficznych cech, które mają świadczyć o zahamowaniu emocjonalnym i problemach psychologicznych, a także większej liczby wypowiedzi mówiących o ruchu niezdecydowanym, skulonym lub wyrażonym $\mathrm{w}$ formie postawy. Według Piotrowskiego jakość i liczba wypowiedzi $M$ nie zmieniają się szybko i pozostają względnie trwałe w ciągu życia człowieka, ale muszę przyznać, że nie można wykluczyć takiej możliwości by ewentualne zaburzenia stwierdzane w wypowiedziach $M$ były częściowo lub w zupełności wynikiem stresu związanego $\mathrm{z}$ chorobą psychiczną dziecka.

\section{Materiał i metoda}

Zbadałam 31 par rodziców z dzieckiem chorym na schizofrenię paranoidalną oraz jedną matkę $\mathrm{z}$ chorą córką - ojciec z przyczyn losowych nie poddał się badaniu. Średni wiek matek wynosił 48,2 lat, a średni wiek ojców 51,4. Wśród ojców przeważało wykształcenie wyższe (52\%); wykształcenie średnie miało $26 \%$, zawodowe $12 \%$, a podstawowe $10 \%$. Wśród matek przeważało wykształcenie średnie (47\%). Wykształcenie wyższe i półwyższe miało 38\%, zawodowe 9\%, a wykształcenie podstawowe miało $6 \%$ matek.

Grupę kontrolną stanowiło 21 par rodziców dzieci zdrowych. Średni wiek matek wynosił 45,7 lat, a ojców 47,5. Wśród ojców przeważało wykształcenie średnie (48\%), wykształcenie wyższe miało 33\%, a zawodowe 19\%. W grupie zdrowych matek również przeważało wykształcenie średnie (52\%), wykształcenie wyższe miało $20 \%$, a 19\% matek miało wykształcenie zawodowe. Rodzice mający zdrowe dzieci byli więc nieco młodsi i nieco słabiej wykształceni niż rodzice dzieci chorych. Rodziny „chore” przeważnie pochodziły ze stosunkowo dużego miasta (53\%), a rodziny „zdrowe” zarówno ze stosunkowo dużych jak i ze stosunkowo małych miast (po 43\%). Pochodzenie wiejskie miało 18\% rodzin „chorych” i 14\% rodzin „zdrowych”.

Badanie przeprowadziłam osobiście za pomocą testu projekcyjnego Rorschacha. Rodziców dzieci chorych na schizofrenię paranoidalną (wg DSM-IV) badałam w końcowej fazie hospitalizacji ich dzieci, ta faza leczenia sprzyjała bowiem nieco mniejszemu poziomowi stresu u wszystkich członków rodziny. Badanie odbywało się na terenie Kliniki Psychiatrii UM w Lublinie, w gabinecie psychologicznym. Rodziców nie mających chorego psychicznie dziecka rekrutowałam z personelu Kliniki Psychiatrii oraz z personelu ZOZ w Lubartowie i w tym ostatnim przypadku badanie przeprowadzałam w Poradni Zdrowia Psychicznego $\mathrm{w}$ gabinecie psychologicznym. Ten sposób przeprowadzenia badań sprawił, że miałam wiedzę o tym, do której z dwu grup badanych należy poszczególna osoba. Wszyscy badani wyrazili zgodę na wykonanie testu, wszystkich też informowałam o anonimowym i czysto teoretycznym celu badania. Rodzicom mającym chore dziecko wyjaśniałam, że udział w badaniu nie będzie miał żadnego wpływu na leczenie ich dziecka, ale być może przyczyni się do lepszego zrozumienia choroby, na którą ono cierpi.

W analizie wypowiedzi uzyskanych podczas badania uwzględniłam liczbę wszystkich wypowiedzi (dysproporcje mogłyby wpływać na charakter spostrzeżeń). Następnie wzięłam pod uwagę liczbę wypowiedzi mówiących o ruchu ludzkim $(M)$, liczbę wypowiedzi mówiących o ruchu zwierzęcym $(F M)$ oraz liczbę wypowiedzi mówiących o ruchu przedmiotów nieożywionych $(m)$. Wszystkie te liczby były ujęte globalnie, czyli w odniesieniu do całego badania testem, jak i w odniesieniu do poszczególnych tablic testu. Wymienione rodzaje ruchów łączyłam z poszczególnymi jakościami ruchu: ruchem rozmachowym, ruchem skulonym, ruchem niezdecydowanym, ruchem rozmachowym $\mathrm{w}$ formie postawy, ruchem skulonym $\mathrm{w}$ formie postawy, ruchem niezdecydowanym $\mathrm{w}$ formie postawy oraz z ruchem złożonym. Kolejną zmienną zależną była liczba wszystkich jakości ruchów ujętych globalnie (pojawiających się w całym badaniu testem). Wszystkie zmienne wyróżnione $\mathrm{w}$ ten sposób traktowałam jako zmienne odzwierciedlające swoistość ukształtowania roli prototypowej.

Jako zmienne mogące łączyć się z trudnościami (lub z łatwością) ekspresji roli prototypowej przyjęłam: $M$ nieadekwatne do kształtu plamy $(M-), M$ odniesione 
do części ciała ludzkiego, $M$ odniesione do całej plamy $(M W), M$ odniesione do dużej, dobrze wydzielonej części plamy $(M D), M$ odniesione do małej lub nietypowo, $M$ bez uwzględnienia kształtu plamy ( $M$ bez formy), $M$ mówiące o ruchu postaci quasi ludzkich, $M$ pojawiające się w pozytywnym kontekście emocjonalnym ( $M C O P$ ) oraz $M$ zabarwione agresywnymi emocjami ( $M A G$ ). Uwzględniłam też wypowiedzi mówiące o ruchu a jednocześnie wykorzystujące do interpretacji plamy światłocień lub kolor.

Wszystkie wyróżnione zmienne są tymi samymi zmiennymi, które uwzględniałam przy porównaniu grupy biologicznych dzieci badanych par rodziców, podzielonych na grupę dzieci chorych i grupę dzieci zdrowych[38]. W niniejszym opracowaniu wykorzystuję system interpretacji wypowiedzi opracowany przez Piotrowskiego, sygnatury $M C O P$ i $M A G$ zapożyczyłam z systemu Exnera; Piotrowski nie używał tych sygnatur ale uwzględniał kontekst emocjonalny wypowiedzi. Światłocień i kolor dodane do spostrzeganego ruchu mówią, obok samej treści wypowiedzi, o zabarwieniu emocjonalnym danego spostrzeżenia. Można założyć, że w ekspresji roli prototypowej szczególne znaczenie odgrywa lęk. Postawiłam też więc pytanie o zależność miedzy wypowiedziami „ruchowymi” a wypowiedziami uwzględniającymi światłocień. Liczbę tych ostatnich wypowiedzi, ujętych w całym badaniu, niezależnie od tego czy łączyły się z wypowiedziami „ruchowymi” czy nie, traktowałam, zgodnie z ogólnie przyjętą zasadą jako miarę lęku. Nie uwzględniałam wartości ważonych tych wypowiedzi, ponieważ w całej analizie posługiwałam się częstością pojawiania się poszczególnych typów wypowiedzi, bez uwzględniania relacji między sygnaturami.

\section{Wyniki}

Kształt rozkładu zmiennych oszacowałam na podstawie testu Kołmogorowa-Smirnowa, którego wyniki stanowiły punkt wyjścia przy doborze testu do porównań dotyczących różnic międzygrupowych. Weryfikację różnic międzygrupowych w zakresie zmiennych, których rozkłady cechowała zbieżność z rozkładem normalnym, oparłam na parametrycznym teście $t$ Studenta. Do analizy istotności różnic międzygrupowych w zakresie zmiennych, których rozkłady odbiegały istotnie od rozkładu normalnego, posłużył nieparametryczny test U Manna-Whitneya. Do oceny współzależności między wypowiedziami „światłocieniowymi” a wypowiedziami mówiącymi o poszczególnych rodzajach ruchu wykorzystałam $r$ Pearsona (gdy zmienne miały rozkład normalny) lub rho Spearmana (gdy rozkład zmiennych odbiegał od rozkładu normalnego).

Pierwszą czynnością było sprawdzenie, czy poszczególne grupy badanych różnią się liczbą wszystkich wypowiedzi podanych w całym badaniu, liczba ta bowiem może pośrednio wpływać na pojawienie się różnych typów spostrzeżeń. Odpowiednie dane zawarte są w Tabeli 1.

Tabela 1. Średnia liczba wypowiedzi, odchylenia standardowe i istotności różnic między poszczególnymi grupami badanych

\begin{tabular}{|c|c|c|c|c|c|}
\hline Grupa & Średnia & $\begin{array}{l}\text { Odchylenie } \\
\text { standardowe }\end{array}$ & $\begin{array}{l}\text { U Manna- } \\
\text { Whitneya }\end{array}$ & $z$ & $\begin{array}{l}\text { Istotność } \\
\text { asomptyczna }\end{array}$ \\
\hline $\begin{array}{l}\text { Rodzice dzieci zdrowych } \\
N=42\end{array}$ & 26,43 & 12,114 & \multirow{2}{*}{1143,500} & \multirow{2}{*}{$-1,175$} & \multirow{2}{*}{,240 } \\
\hline $\begin{array}{l}\text { Rodzice dzieci chorych } \\
N=63\end{array}$ & 27,71 & 11,639 & & & \\
\hline $\begin{array}{l}\text { Matki dzieci zdrowych } \\
N=21\end{array}$ & 31,05 & 15,253 & \multirow{2}{*}{292,500} & \multirow{2}{*}{$-0,792$} & \multirow{2}{*}{,429 } \\
\hline $\begin{array}{l}\text { Matki dzieci chorych } \\
N=32\end{array}$ & 27,88 & 13,312 & & & \\
\hline $\begin{array}{l}\text { Ojcowie dzieci zdrowych } \\
N=21\end{array}$ & 21,81 & 4,833 & \multirow{2}{*}{177,500} & \multirow{2}{*}{$-2,768$} & \multirow{2}{*}{, $006^{*}$} \\
\hline $\begin{array}{l}\text { Ojcowie dzieci chorych } \\
N=31\end{array}$ & 27,55 & 9,838 & & & \\
\hline
\end{tabular}

$$
* \mathrm{p} \leq, 01
$$


Jak widzimy z danych zawartych w Tabeli 1., rodzice dzieci chorych nie dali mniejszej liczby wypowiedzi niż rodzice dzieci zdrowych i podobnie, matki chorych dzieci nie różniły się pod tym względem od matek dzieci chorych. Różnili się natomiast miedzy sobą ojcowie dzieci chorych i ojcowie dzieci zdrowych i to ci ostatni wygenerowali istotnie mniej wszystkich wypowiedzi w całym badaniu.

Grupa rodziców chorych dzieci różniła się istotnie od grupy rodziców dzieci zdrowych w ośmiu zmiennych, a w dwu zmiennych różnice bardzo zbliżały się do istotności; ujęte jest to w Tabeli 2.

Tabela 2. Różnice i ich istotności w poszczególnych zmiennych między grupq rodziców zdrowych dzieci a grupq rodziców chorych dzieci

\begin{tabular}{|c|c|c|c|c|c|c|c|}
\hline \multirow[t]{2}{*}{ Zmienna zależna } & \multicolumn{2}{|c|}{$\begin{array}{l}\text { Rodzice dzieci } \\
\text { zdrowych } \\
N=42\end{array}$} & \multicolumn{2}{|c|}{$\begin{array}{l}\text { Rodzice dzieci } \\
\text { chorych } N=63\end{array}$} & \multirow[t]{2}{*}{$z$} & \multirow[t]{2}{*}{$\begin{array}{l}\text { U Manna- } \\
\text { Whitneya }\end{array}$} & \multirow[t]{2}{*}{ Istotność } \\
\hline & $M$ & $S D$ & $M$ & $S D$ & & & \\
\hline Liczba wypowiedzi na tablicę VI & 2,19 & 1,254 & 1,92 & 1,653 & $-1,937$ & 1045,000 & 053 \\
\hline $\begin{array}{l}\text { Liczba wypowiedzi } M \\
\text { w całym badaniu }\end{array}$ & 2,79 & 1,907 & 0,35 & 0,925 & $-2,073$ & 1012,000 & ,038* \\
\hline $\begin{array}{l}\text { Liczba wypowiedzi } \\
\text { M na tablicę VII }\end{array}$ & 0,31 & 0,468 & 0,15 & 0,358 & $-2,004$ & 1088,000 &, $045^{*}$ \\
\hline $\begin{array}{l}\text { Liczba wypowiedzi } \\
\text { MW na tablicę II }\end{array}$ & 0,17 & 1,129 & 0,07 & 0,309 & $-1,952$ & 1151,500 & 051 \\
\hline $\begin{array}{l}\text { Liczba wypowiedzi } \\
\text { MW na tablicę III }\end{array}$ & 1,21 & 1,523 & 0,72 & 0,710 & $-2,369$ & 988,000 & ,018* \\
\hline $\begin{array}{l}\text { Liczba wypowiedzi } \\
\text { MW na tablicę VII }\end{array}$ & 0,05 & 0,216 & 0,00 & 0,000 & $-2,947$ & 1065,000 &, $003^{* *}$ \\
\hline $\begin{array}{l}\text { Liczba wypowiedzi } \\
\text { MD na tablicę IV }\end{array}$ & 0,07 & 0,261 & 0,00 & 0,000 & $-2,125$ & 1209,000 &, $034^{*}$ \\
\hline $\begin{array}{l}\text { Liczba wypowiedzi M } \\
\text { ze światłocieniem }\end{array}$ & 0,57 & 1,039 & 0,23 & 0,643 & $-2,052$ & 1063,000 & ,031* \\
\hline $\begin{array}{l}\text { Liczba wypowiedzi M } \\
\text { o treści zwierzęcej }\end{array}$ & 0,21 & 0,470 & 0,05 & 0,218 & $-2,318$ & 1115,500 & ,020* \\
\hline $\begin{array}{l}\text { Liczba wypowiedzi } \\
\text { uwzględniających światłocień }\end{array}$ & 4,45 & 3,72 & 6,77 & 4,568 & $-3,331$ & 817,000 &, $001^{* * *}$ \\
\hline
\end{tabular}

${ }^{*} p \leq, 05 ;{ }^{* *} p \leq, 005 ; * * * \leq, 001$

M - wypowiedzi mówiq̨ce o ruchu ludzkim

MW - wypowiedzi mówiące o ruchu ludzkim odniesionym do całej plamy

MD - wypowiedzi mówiq̨ce o ruchu ludzkim odniesionym do dużej / dobrze wydzielonej części plamy

Jak pokazują dane ujęte w Tabeli 2., rodzice chorych dzieci istotnie rzadziej spostrzegali postać ludzką w ruchu $(M)$, jeśli uwzględniłam całe badanie testem, a także istotnie rzadziej widzieli ruch ludzki na tablicy VII. Rodzice chorych dzieci rzadziej odnosili postać ludzką w ruchu do całej plamy na tablicy II, III i VII, natomiast na tablicy IV trudniej im było zobaczyć ruch ludzki w dużej, dobrze wydzielonej części. Rodzice ci rzadziej też łączyli ruch ludzki ze światłocieniem. A jednak, wypowiedzi uwzględniające światłocień pojawiające się w całym badaniu (a nie jedynie w odniesieniu do ruchów) wysoce istotnie częściej występowały w grupie rodziców dzieci chorych. Rodzice zdrowych dzieci istotnie częściej widzieli ruch typowy dla człowieka, ale przypisywany zwierzętom. Rodzice zdrowych dzieci dali też więcej wypowiedzi na tablicę VI (choć różnica zbliżała się tu jedynie do istotności).

Matki chorych dzieci różniły się od matek dzieci zdrowych jedynie $\mathrm{w}$ dwu zmiennych, ale różnice te były wysoce istotne. Odpowiednie dane zawarte są w Tabeli 3. 
Tabela 3. Różnice i ich istotności w wybranych zmiennych między grupq matek dzieci zdrowych i grupq matek dzieci chorych

\begin{tabular}{|c|c|c|c|c|c|c|c|}
\hline \multirow[t]{2}{*}{ Zmienna zależna } & \multicolumn{2}{|c|}{$\begin{array}{l}\text { matki dzieci } \\
\text { zdrowych } N=21\end{array}$} & \multicolumn{2}{|c|}{$\begin{array}{l}\text { matki dzieci } \\
\text { chorych } N=32\end{array}$} & \multirow[t]{2}{*}{$Z$} & \multirow{2}{*}{$\begin{array}{l}\text { U Manna- } \\
\text { Whitneya }\end{array}$} & \multirow[t]{2}{*}{ Istotność } \\
\hline & $M$ & $S D$ & $M$ & $S D$ & & & \\
\hline Liczba wypowiedzi na tablicę VI & 2,81 & 1,401 & 2,09 & 1,838 & $-2,622$ & 198,000 &, $009 *$ \\
\hline $\begin{array}{l}\text { Liczba wypowiedzi } \\
\text { MW na tablicę VI }\end{array}$ & 0,29 & 0,463 & 0,03 & 0,180 & $-2,602$ & 243,000 &, $009 *$ \\
\hline
\end{tabular}

$* p \leq, 01$

MW - wypowiedzi mówiq̨ce o ruchu ludzkim odniesionym do całej plamy

Jak mówią dane zawarte w Tabeli 3., matki chorych dzieci dawały istotnie mniej wypowiedzi na tablicę VI, a także mniej wypowiedzi $M W$ na tablicę VII.
Dużo więcej różnic ujawniło się między grupą ojców dzieci chorych a grupą ojców zdrowych dzieci, co ujęte jest w Tabeli 4.

Tabela 4. Różnice i ich istotności w poszczególnych zmiennych między grupq ojców dzieci zdrowych a grupq ojców dzieci chorych

\begin{tabular}{|c|c|c|c|c|c|c|c|}
\hline \multirow[t]{2}{*}{ Zmienna zależna } & \multicolumn{2}{|c|}{$\begin{array}{l}\text { Ojcowie dzieci } \\
\text { zdrowych } N=21\end{array}$} & \multicolumn{2}{|c|}{$\begin{array}{l}\text { Ojcowie dzieci } \\
\text { chorych } N=31\end{array}$} & \multirow[t]{2}{*}{$z$} & \multirow{2}{*}{$\begin{array}{l}U \\
\text { Manna- } \\
\text { Whitneya }\end{array}$} & \multirow[t]{2}{*}{ Istotność } \\
\hline & $M$ & $S D$ & $M$ & $S D$ & & & \\
\hline Liczba wypowiedzi na tablicę VIII & 2,10 & 0,831 & 3,26 & 1,548 & $-2,944$ & 173,000 &, $003^{* *}$ \\
\hline Liczba wypowiedzi M & 1,76 & 0,831 & 1,26 & 999 & $-2,091$ & 221,500 &, $037^{*}$ \\
\hline Liczba wypowiedzi na tablicę III & 1,10 & 0,539 & 0,77 & ,762 & $-1,977$ & 235,000 &, $048^{*}$ \\
\hline $\begin{array}{l}\text { Liczba wypowiedzi } \\
\text { M na tablicę VII }\end{array}$ & 0,38 & 0,498 & 0,10 & ,301 & $-2,438$ & 233,000 &, $015^{*}$ \\
\hline $\begin{array}{l}\text { Liczba wypowiedzi } \\
\text { MW na tablicę II }\end{array}$ & 0,24 & 0,436 & 0,03 & ,180 & $-2,258$ & 258,500 &, $024^{*}$ \\
\hline $\begin{array}{l}\text { Liczba wypowiedzi } \\
\text { MW na tablicę III }\end{array}$ & 1,05 & 0,590 & 0,58 & ,672 & $-2,888$ & 193,000 &, $004^{* *}$ \\
\hline $\begin{array}{l}\text { Liczba ruchów M skulonych } \\
\text { w formie postawy }\end{array}$ & 0,24 & 0,539 & 0,00 &, 000 & $-2,503$ & 263,500 &, $012^{*}$ \\
\hline $\begin{array}{l}\text { Liczba wypowiedzi MC } \\
\text { łączonych z udorem }\end{array}$ & 0,57 & 0,811 & 0,19 &, 543 & $-2,077$ & 243,500 &, $038^{*}$ \\
\hline Liczba ruchów złożonych & 0,00 & 0,000 & 0,16 & ,374 & $-1,917$ & 273,000 & 055 \\
\hline
\end{tabular}

$* p \leq, 05 ; * * \leq, 01$

M - wypowiedzi mówiq̨ce o ruchu ludzkim

MW - wypowiedzi mówiq̨ce o ruchu ludzkim odniesionym do całej plamy

Dane zawarte w Tabeli 4. mówią, że ojcowie dzieci chorych dali więcej wypowiedzi na tablicę VIII, mniej wypowiedzi $M$ na tablicę III i VII, mniej wypowiedzi $M W$ na tablicę II i III i żadnej wypowiedzi (w całym badaniu) mówiącej o ruchu $M$ skulonym w formie postawy. W grupie ojców chorych dzieci rzadziej pojawiały się też wypowiedzi $M \mathrm{w}$ połączeniu z kolorem i rzadziej występowały wypowiedzi $M$ wszystkich jakości wziętych 
razem w całym badaniu. Ojcowie dzieci chorych wykazali różnica zbliżała się tu jedynie do istotności. tendencję do częstszego mówienia o ruchu złożonym, choć

Tabela 5. Różnice i ich istotności w poszczególnych zmiennych między grupq ojców dzieci zdrowych a grupq ojców dzieci chorych

\begin{tabular}{|l|l|l|l|l|l|l|}
\hline \multirow{2}{*}{ Zmienna zależna } & \multicolumn{2}{l|}{$\begin{array}{l}\text { Ojcowie dzieci } \\
\text { zdrowych N=21 }\end{array}$} & \multicolumn{2}{l|}{$\begin{array}{l}\text { Ojcowie dzieci } \\
\text { chorych N=31 }\end{array}$} & \multirow{2}{*}{ Test + } & Istotność \\
\cline { 2 - 7 } & $M$ & $S D$ & $M$ & $S D$ & 2,324 &, $024^{*}$ \\
\hline Liczba wypowiedzi na tablicę X & 2,67 & 1,390 & 3,87 & 2,078 & 2,281 &, $027^{*}$ \\
\hline Liczba wypowiedzi MW & 1,62 & 1,071 & 0,90 & 1,136 & 3,795 &, $000^{* *}$ \\
\hline $\begin{array}{l}\text { Liczba wypowiedzi } \\
\text { „Światłocieniowych” }\end{array}$ & 3,24 & 2,022 & 6,19 & 3,572 & 3,25 \\
\hline
\end{tabular}

${ }^{*} p \leq, 05 ; * *, 001$

MW - wypowiedzi mówiq̨ce o ruchu ludzkim odniesionym do całej plamy

Jak widzimy na podstawie danych zawartych w Tabeli 5., ojcowie chorych dzieci dali więcej wypowiedzi na tablicę X i wysoce istotnie częściej wykorzystywali do interpretacji plam światłocień. Liczba wypowiedzi $M W$ podana w całym badaniu testem w grupie ojców dzieci chorych była istotnie mniejsza niż w grupie ojców dzieci zdrowych.

W kolejnych tabelach zawarte są dane mówiące o współwystępowaniu różnych jakości ruchów z wypowiedziami „światłocieniowymi” (lękiem).

W Tabelach 6. i 7. zawarte są informacje dotyczące całej badanej grupy.

Tabela 6. Współczynniki korelacji $r$ Pearsona $w$ grupie wszystkich rodziców (N=105) między zmienna „światłocienie” a zmiennymi dotyczącymi jakości ruchu

\begin{tabular}{|l|l|l|}
\hline $\begin{array}{l}\text { Zmienne dotyczace } \\
\text { jakości ruchu }\end{array}$ & $\begin{array}{l}\text { Współczynnik } \\
\text { r Pearsona }\end{array}$ & Istotność \\
\hline $\begin{array}{l}\text { Wszystkie ruchy } \\
\text { rozmachowe }\end{array}$ &, $582^{* * *}$ &, 000 \\
\hline $\begin{array}{l}\text { Wszystkie ruchy } \\
\text { skulone }\end{array}$ &, $244^{*}$ &, 012 \\
\hline
\end{tabular}

${ }^{*} p \leq, 05 ;{ }^{* * *} p \leq, 001$

Dane ujęte w Tabeli 6. mówią, że wszystkie ruchy rozmachowei wszystkie ruchy skulone współwystępowały z wypowiedziami „światłocieniowymi”.

W Tabeli 7. podane są kolejne związki poszczególnych jakości ruchów a wypowiedziami „światłocieniowymi”.
Tabela 7. Wartości rho Spearnana między zmienna „Światłocienie” a zmiennymi dotyczacymi jakości ruchu w grupie wszystkich rodziców $(N=105)$

\begin{tabular}{|l|l|l|}
\hline $\begin{array}{l}\text { Zmienne dotyczqce } \\
\text { jakości ruchu }\end{array}$ & $\begin{array}{l}\text { rho } \\
\text { Spearnana }\end{array}$ & istotność \\
\hline $\begin{array}{l}\text { Wszystkie ruchy } \\
\text { niezdecydowane }\end{array}$ &, 84 &, 393 \\
\hline $\begin{array}{l}\text { Wszystkie ruchy } \\
\text { rozmachowe - postawa }\end{array}$ &, 114 &, 246 \\
\hline $\begin{array}{l}\text { Wszystkie ruchy } \\
\text { skulone - postawa }\end{array}$ &, $280^{* *}$ &, 004 \\
\hline $\begin{array}{l}\text { Wszystkie ruchy } \\
\text { niezdecydowane } \\
\text { - postawa }\end{array}$ &, 100 &, 308 \\
\hline $\begin{array}{l}\text { Wszystkie ruchy } \\
\text { złożone }\end{array}$ &, $326^{* *}$ &, 001 \\
\hline Wszystkie jakości ruchu &, $303^{* *}$ &, 002 \\
\hline
\end{tabular}

** $p \leq, 01$

Jak widzimy na podstawie danych widocznych w Tabeli 7., wszystkie wypowiedzi mówiące o ruchach skulonych w formie postawy, ruchach złożonych i ogólnie wziętych wszystkich jakościach ruchu istotnie współwystępowały z wypowiedziami „światłocieniowymi”.

W Tabeli 8. ujęte są współzależności między jakościami ruchów a światłocieniem, jakie wystąpiły w grupie rodziców dzieci chorych, zarówno ojców jak i matek. 
Tabela 8. Współczynniki korelacji $r$ Pearsona $w$ grupie rodziców chorych dzieci $(N=63)$ między zmiennq „światłocienie” a zmiennymi dotyczącymi jakości ruchu

\begin{tabular}{|l|l|l|}
\hline $\begin{array}{l}\text { Zmienne dotyczq̨e } \\
\text { jakości ruchu }\end{array}$ & $\begin{array}{l}\text { Współczynnik } \\
\text { r Pearsona }\end{array}$ & istotność \\
\hline $\begin{array}{l}\text { Wszystkie ruchy } \\
\text { rozmachowe }\end{array}$ &, $691^{* * *}$ &, 000 \\
\hline $\begin{array}{l}\text { Wszystkie ruchy } \\
\text { skulone }\end{array}$ &, 179 &, 160 \\
\hline
\end{tabular}

$* * * p \leq, 001$

Tabela 8. pokazuje, że wystąpiły istotne związki między zmienną „światłocienie” a ruchami rozmachowymi i ruchami złożonymi.

W Tabeli 9. ujęte są kolejne korelacje dotyczące rodziców dzieci chorych, zarówno ojców jak i matek.

Tabela 9. Wartości rho Spearnana między zmienna „światłocienie” a zmiennymi dotyczacymi jakości ruchu w grupie rodzicó $w$ chorych dzieci $(N=63)$

\begin{tabular}{|l|l|l|}
\hline $\begin{array}{l}\text { Zmienne dotyczqce } \\
\text { jakości ruchu }\end{array}$ & $\begin{array}{l}\text { rho } \\
\text { Spearnana }\end{array}$ & istotność \\
\hline $\begin{array}{l}\text { Wszystkie ruchy } \\
\text { niezdecydowane }\end{array}$ &, 175 &, 169 \\
\hline $\begin{array}{l}\text { Wszystkie ruchy } \\
\text { rozmachowe - postawa }\end{array}$ &, 203 &, 111 \\
\hline $\begin{array}{l}\text { Wszystkie ruchy } \\
\text { skulone - postawa }\end{array}$ &, $270^{*}$ &, 032 \\
\hline $\begin{array}{l}\text { Wszystkie ruchy } \\
\text { niezdecydowane } \\
\text { - postawa }\end{array}$ &, 100 &, 437 \\
\hline $\begin{array}{l}\text { Wszystkie ruchy } \\
\text { złożone }\end{array}$ &, $250^{*}$ &, 001 \\
\hline Wszystkie jakości ruchu &, $418^{* *}$ & \\
\hline
\end{tabular}

${ }^{*} p \leq, 05 ;{ }^{* *} p \leq, 01$

Jak pokazują wskaźniki korelacji zawarte w Tabeli 9., w grupie rodziców chorych dzieci ukazała się bardzo istotna współzależność między wypowiedziami mówiącymi o ruchu skulonym w formie postawy, o ruchu złożonym oraz wypowiedzi dotyczące wszystkich jakości ruchu a wypowiedziami „światłocieniowymi”.

Współczynniki rho Spearmana dla grupy rodziców zdrowych dzieci zawarte są w Tabeli 10.
Tabela 10. Wartości rho Spearnana między zmienna „Światłocienie” a zmiennymi dotyczacymi jakości ruchu w grupie rodziców zdrowych dzieci $(N=42)$

\begin{tabular}{|l|l|l|}
\hline $\begin{array}{l}\text { Z mienne dotyczace } \\
\text { jakości ruchu }\end{array}$ & $\begin{array}{l}\text { rho } \\
\text { Spearnana }\end{array}$ & istotność \\
\hline $\begin{array}{l}\text { Wszystkie ruchy } \\
\text { rozmachowe }\end{array}$ &, $512^{* *}$ &, 001 \\
\hline Wszystkie ruchy skulone &,- 075 &, 637 \\
\hline $\begin{array}{l}\text { Wszystkie ruchy } \\
\text { niezdecydowane }\end{array}$ &, 039 &, 808 \\
\hline $\begin{array}{l}\text { Wszystkie ruchy } \\
\text { rozmachowe-postawa }\end{array}$ &, 133 &, 401 \\
\hline $\begin{array}{l}\text { Wszystkie ruchy } \\
\text { skulone - postawa }\end{array}$ &, 264 &, 091 \\
\hline $\begin{array}{l}\text { Wszystkie ruchy } \\
\text { niezdecydowane } \\
\text { - postawa }\end{array}$ &, 126 &, 428 \\
\hline $\begin{array}{l}\text { Wszystkie ruchy } \\
\text { złożone }\end{array}$ &, $477^{* *}$ &, 264 \\
\hline Wszystkie jakości ruchu &, 176 &, 001 \\
\hline
\end{tabular}

${ }^{* *} p \leq, 01$;

Jak widzimy $\mathrm{z}$ danych zawartych w Tabeli 10. w grupie rodziców zdrowych dzieci ukazała się istotna współzależność między wypowiedziami „światłocieniowym,” a wypowiedziami mówiącymi o ruchu rozmachowym oraz wypowiedziami dotyczącymi złożonych.

Korelacje odnoszące się do grupy wszystkich ojców zawarte są w Tabeli 11.

Tabela 11. Wartości rho Spearnana między zmienna „światłocienie” a zmiennymi dotyczącymi jakości ruchu w grupie wszystkich ojców ( $N=52)$

\begin{tabular}{|l|l|l|}
\hline $\begin{array}{l}\text { Zmienne dotyczqce } \\
\text { jakości ruchu }\end{array}$ & $\begin{array}{l}\text { rho } \\
\text { Spearnana }\end{array}$ & istotność \\
\hline $\begin{array}{l}\text { Wszystkie ruchy } \\
\text { rozmachowe }\end{array}$ &, $395^{* *}$ &, 004 \\
\hline Wszystkie ruchy skulone &,- 042 &, 769 \\
\hline $\begin{array}{l}\text { Wszystkie ruchy } \\
\text { niezdecydowane }\end{array}$ &,- 044 &, 754 \\
\hline $\begin{array}{l}\text { Wszystkie ruchy } \\
\text { rozmachowe - postawa }\end{array}$ &, 031 &, 828 \\
\hline $\begin{array}{l}\text { Wszystkie ruchy } \\
\text { skulone - postawa }\end{array}$ &, 257 &, 066 \\
\hline $\begin{array}{l}\text { Wszystkie ruchy } \\
\text { niezdecydowane - postawa }\end{array}$ &, 089 &, 529 \\
\hline
\end{tabular}




\begin{tabular}{|l|l|l|}
\hline $\begin{array}{l}\text { Zmienne dotyczace } \\
\text { jakości ruchu }\end{array}$ & $\begin{array}{l}\text { rho } \\
\text { Spearnana }\end{array}$ & istotność \\
\hline Wszystkie ruchy złożone &, $287^{*}$ &, 039 \\
\hline Wszystkie jakości ruchu &, 181 &, 199 \\
\hline
\end{tabular}

${ }^{*} p \leq, 05 ;{ }^{* *} p \leq, 01$;

W grupie wszystkich ojców zaznaczyły się dwie istotne współzależności: między wypowiedziami „światłocieniowymi” a wypowiedziami dotyczącymi ruchu rozmachowego oraz wypowiedziami dotyczącymi ruchu złożonego.

Współczynniki korelacji odniesione do grupy wszystkich matek widoczne są w Tabeli 12 i 13.

Tabela 12. Współczynnik korelacji r Pearsona $w$ grupie wszystkich matek (N=53) między zmiennq "światłocienie" a wszystkimi ruchami rozmachowymi

\begin{tabular}{|l|l|l|}
\hline $\begin{array}{l}\text { Zmienna dotyczaca } \\
\text { jakości ruchu }\end{array}$ & $\begin{array}{l}\text { Współczynnik } \\
\text { r Pearsona }\end{array}$ & istotność \\
\hline $\begin{array}{l}\text { Wszystkie ruchy } \\
\text { rozmachowe }\end{array}$ &, $670^{* * *}$ &, 000 \\
\hline
\end{tabular}

$* * * p \leq .01$;

W grupie wszystkich matek wystąpiła istotna współzależność między wypowiedziami „światłocieniowymi’ a wypowiedziami mówiącymi o rozmachowym.

W Tabeli 13. ukazane są kolejne korelacje między zmienną „światłocienie” a dalszymi jakościami ruchu.

Tabela 13. Wartości rho Spearnana między zmienna „światłocienie” a zmiennymi dotyczq̨cymi jakości ruchu w grupie wszystkich matek $(N=53)$

\begin{tabular}{|l|l|l|}
\hline $\begin{array}{l}\text { Zmienne dotyczące } \\
\text { jakości ruchu }\end{array}$ & $\begin{array}{l}\text { rho } \\
\text { Spearnana }\end{array}$ & istotność \\
\hline Wszystkie ruchy skulone &, 265 &, 055 \\
\hline $\begin{array}{l}\text { Wszystkie ruchy } \\
\text { niezdecydowane }\end{array}$ &, 159 &, 256 \\
\hline $\begin{array}{l}\text { Wszystkie ruchy } \\
\text { rozmachowe - postawa }\end{array}$ &, 231 &, 095 \\
\hline $\begin{array}{l}\text { Wszystkie ruchy } \\
\text { skulone - postawa }\end{array}$ &, 263 &, 057 \\
\hline $\begin{array}{l}\text { Wszystkie ruchy } \\
\text { niezdecydowane } \\
\text { - postawa }\end{array}$ &, 138 &, 323 \\
\hline Wszystkie ruchy złożone &, $324^{*}$ &, 018 \\
\hline Wszystkie jakości ruchu & $440^{* *}$ &, 001 \\
\hline
\end{tabular}

$* p \leq .05 ;^{* *} p \leq .01$
Z danych zawartych w Tabeli 13. widzimy, że wypowiedzi uwzględniające światłocień współwystępowały $\mathrm{z}$ ruchem złożonym, a także wszystkimi jakościami ruchu wziętymi globalnie.

\section{Dyskusja}

Rodzice mający chore na schizofrenię dziecko istotnie rzadziej spostrzegali postać ludzką w ruchu niż rodzice mający tylko zdrowe dzieci. Jest to bardzo ważny aspekt reagowania na plamy atramentowe. Za Piotrowskim możemy powiedzieć, że rodzice chorych dzieci nie ujawnili swej indywidualności w tak wyrazisty sposób, jak uczynili to rodzice dzieci zdrowych, a więc prawdopodobnie ich rola prototypowa nie była tak silnym wzorcem nadającym kształt całemu życiu, jak miało to miejsce w przypadku rodziców dzieci zdrowych. Mniejsza liczba wypowiedzi $M$ może łączyć się również z mniejszą dojrzałością i integracją psychiczną, a także $\mathrm{z}$ nieco osłabioną samokontrolą. Co więcej, ekspresja tych mniej licznych reakcji $M$ nierzadko była utrudniona. Wyrażało się to między innymi mniejszą liczbą wypowiedzi $M$ odniesionych do całej plamy widniejącej na tablicy. Szczególnie rzadziej wypowiedzi $M W$ pojawiały się na tablicę II, III i VII, a właśnie na tych tablicach ujrzenie w całej plamie postaci ludzkiej nie jest trudne. Na tablicy II wystarczy włączyć czerwone górne plamy do całości spostrzeżenia interpretując je np. jako kaptury. Na tablicy VII widzenie główek kobiecych lub dziecięcych jest tak częste, że wypowiedziom takim nadano status wypowiedzi popularnej. I tutaj połączenie spostrzeżenia główek z resztą plamy nie jest trudne, a nawet jest czymś, co się niejako samo narzuca. Rodzice chorych dzieci podali mniej wypowiedzi $M$ i $M W$ na tę tablicę, można więc powiedzieć, że $\mathrm{w}$ ten sposób ujawnili poważny deficyt w takim reagowaniu, które jest typowe dla ogółu badanych.

Bardzo ważnym wynikiem była mniejsza liczba wypowiedzi $M W$ na tablicę III. W systemie interpretacyjnym Piotrowskiego spostrzeganie ludzi w ruchu w ciemnej plamie traktuje się tu jako wypowiedź $M W$ i nie ma w tym przypadku konieczności włączenia do spostrzeżenia małych czerwonych plam, aby uzyskać sygnaturę $M W$. Piotrowski kierował się tu zasadami psychologii postaci: i rzeczywiście, ciemna plama jest tak dobrą figurą, że wymusza jakby na widzu spostrzeżenie postaci ludzkich. Dlatego właśnie spostrzeżenie ludzi w typowy sposób w tej plamie jest reakcją popularną i kluczową w interpretacji. Możemy nawet powiedzieć, że jest to jedyna w całym teście reakcja, która nie jest traktowana jako dowolna, ale stanowi pewną normę. $\mathrm{Z}$ tego względu wszelkie nieprawidłowości w tej reakcji są niezwykle znaczące i mogą świadczyć o zaburzeniach w ukształtowaniu i ekspresji roli prototypowej. Nietypowe 
widzenie ludzi na tablicy III często bywa oceniane jako nieadekwatne $(M-)$. Rodzice chorych dzieci podali więcej wypowiedzi $M$-, choć różnica ta nie osiągnęła poziomu istotności (z tego też powodu nie zamieściłam odpowiednich danych w Tabeli 2; rodzice dzieci zdrowych: $M=0,07, \mathrm{SD} .=0,261$, rodzice dzieci chorych: $M=0,35$, $\mathrm{SD} .=0,9225, \mathrm{z}=-1,776, \mathrm{U}$ Manna-Whitneya $=1158,000$, istotność $=$,076). Należałoby sprawdzić, czy błędne interpretacje postaci ludzkich na tablicy III nie zaważyły na wyższej liczbie $M-\mathrm{w}$ grupie rodziców $\mathrm{z}$ chorym dzieckiem.

Rodzice chorych dzieci częściej do swych interpretacji plam wykorzystywali światłocień, a więc poziom lęku był u nich istotnie wyższy niż u rodziców dzieci zdrowych. Nie jest łatwo w tym kontekście wyjaśnić częstsze u rodziców zdrowych dzieci spostrzeganie ruchu ludzkiego z jednoczesnym uwzględnieniem światłocienia. Być może, dla rodziców chorych dzieci spostrzeganie człowieka w ruchu było na tyle angażujące, że nie starczało już im energii na dostrzeżenie niuansów w nasyceniu szarej barwy. Jak zobaczymy dalej, ojcowie chorych dzieci rzadziej niż ojcowie dzieci zdrowych łączyli postać ludzką w ruchu z wykorzystaniem koloru; może to świadczyć (podobnie jak brak uwzględniania światłocienia przy spostrzeganiu ludzi w ruchu) w pewnym stopniu o tym, że wypowiedzi rodziców chorych dzieci mówiące o człowieku w ruchu były mniej złożone, uboższe. Rzadziej pojawiających się na tablicę IV wypowiedzi $M D$ (w grupie rodziców chorych dzieci), czyli rzadsze spostrzeganie człowieka w ruchu w dużej i/lub dobrze wydzielonej części wydaje się łączyć z ogólną trudnością związaną $\mathrm{z}$ widzeniem ludzi $\mathrm{w}$ ruchu $\mathrm{w}$ tej grupie badanych. $\mathrm{Na}$ tablicy tej stosunkowo łatwo jest zobaczyć całą postać ludzką lub quasi-ludzką w całej plamie, trudniej natomiast wydzielić odpowiednie części tej plamy. Mniejszą ogólną liczbę wypowiedzi na tablicę VI testu w grupie rodziców chorych dzieci można łączyć z tym, że tablica ta nierzadko wywołuje skojarzenia związane ze sferą seksualną, nie należy jednak zapominać, że plama widniejąca na tej tablicy należy do tych najtrudniejszych do interpretacji. Interesujące jest to, że rodzice zdrowych dzieci istotnie częściej przy pisywali ruch typowy dla ludzi postaciom zwierzęcym. Piotrowski tego typu reakcje łączy z idealistyczną postawą do świata, która w miarę doświadczeń życiowych staje się źródłem rozczarowań, utraty wiary w ludzi i zaufania do nich. Gorycz związana z tą sytuacją może być głęboka i bolesna, może prowadzić do stanów depresyjnych, ale może też sprzyjać cynizmowi i oportunizmowi.

Z porównania wyników matek chorych dzieci i matek zdrowych dzieci oraz ojców chorych dzieci i ojców zdrowych dzieci widzimy, że różnice dotyczyły głównie grupy ojców. Matki różniły się jedynie liczbą wypowiedzi podanych na tablicę VI oraz liczbą wypowiedzi $M W$ na tablicę VII. Nie będę omawiać w tym miejscu tych różnic, omówiłam je bowiem już przy porównaniu wszystkich rodziców „chorych' i „zdrowych”, zwłaszcza że kierunek różnic był taki sam. Można powiedzieć, że to głównie ojcowie chorych dzieci ujawnili swą odmienność pod względem spostrzegania człowieka w ruchu. Przede wszystkim to głównie ojcowie dzieci chorych rzadziej widzieli postać ludzką w ruchu $(M)$ wówczas, gdy wzięto pod uwagę całe badanie, a także istotnie rzadziej dawali tego typu wypowiedzi na tablicę III i VII, a więc na te tablice na których, jak pisałam wcześniej, szczególnie łatwo jest zobaczyć człowieka w ruchu. Ojcowie dzieci chorych istotnie rzadziej widzieli też ludzi w ruchu $\mathrm{w}$ całych plamach oraz rzadziej w odniesieniu do tablicy II i III, a poziom lęku mierzony wypowiedziami „światłocieniowymi” był u nich wysoce istotnie wyższy niż u ojców dzieci zdrowych. Ojcowie chorych dzieci rzadziej łączyli spostrzeganie człowieka w ruchu z uwzględnianiu koloru $(M C)$, co jak już pisałam może świadczyć o uboższym przeżywaniu tego ruchu. Ojcowie dzieci chorych dali istotnie więcej wypowiedzi w całym badaniu, co można rozumieć w ten sposób, że lepiej współpracowali z badającą osobą i być może odczuwali swą zależność od personelu leczącego ich dzieci. Większa ogólna liczba wypowiedzi dodatkowo wzmacnia istotność mniejszej liczby wypowiedzi $M$, ojcowie dzieci chorych mieli bowiem więcej szans, by widzieć ludzi w ruchu, a jednak nie mogli $\mathrm{z}$ jakiś powodów $\mathrm{z}$ tego skorzystać. Ojcowie zdrowych dzieci dali szczególnie mało wypowiedzi na tablicę VIII i X. Można próbować to wyjaśnić trudnościami emocjonalnymi o charakterze neurotycznym. Tablica VIII, jako pierwsza wielobarwna po szeregu tablic ciemnych, może być źródłem zaskoczenia, niemożności poradzenia sobie $\mathrm{z}$ poruszonymi przez barwy emocjami. Tablica X jest trudna do interpretacji, może bowiem wywoływać poczucie chaosu, nadmiaru skojarzeń związanych z poszczególnymi częściami plamy przy niedoborze całościowych ujęć. Możemy podejrzewać, że ojcowie zdrowych dzieci w większym stopniu niż ojcowie dzieci chorych „bronili” się przed badaniem (mniej wypowiedzi podanych w całym badaniu, większe prawdopodobieństwo cynizmu i oportunizmu) i częściej była to obrona prawdopodobnie „skuteczna”, choć reagowali emocjonalnie w sposób podobny do reagowania neurotycznego.

Trudne do interpretacji jest częstsze w grupie ojców dzieci zdrowych mówienie o skulonym ruchu postaci ludzkich $\mathrm{w}$ formie postawy, takich reakcji bowiem spodziewałam się u ojców dzieci chorych; wyniki te nie są spójne z całością uzyskanych rezultatów, jeśli przyjmujemy interpretację jakości ruchów przyjętą przez Piotrowskiego. Większą liczbę wypowiedzi mówiących 
o ruchu złożonym w grupie ojców dzieci chorych, jak myślę, można próbować łączyć z wyższym poziomem lęku u tych badanych, a także być może z ambiwalencją uczuć. Mimo stwierdzonej większej liczby wypowiedzi mówiących o ruchu skulonym w formie postawy w grupie ojców zdrowych dzieci, można powiedzieć (biorąc pod uwagę całość uzyskanych wyników), że ojcowie zdrowych dzieci wykazali się większą dojrzałością w tym sensie, że ich rola prototypowa zaznaczyła się wyraziściej i z większą łatwością była wyrażana, a poziom lęku u nich był istotnie niższy. Należy jeszcze raz podkreślić, że to ojcowie bardziej różnili się między sobą, a nie matki. W literaturze przedmiotu nie są to stwierdzenia częste, o bardziej nasilonej swoistości reagowania u ojców chorych dzieci pisali jednak Hirsh i Leff[1], wspomnę też, że to u ojców chorych dzieci ujawniło się poczucie izolacji i wyobcowania a także pewne oznaki słabszego uspołecznienia[23]. Z drugiej strony u matek bardziej zaznaczały się zaburzenia percepcji i myślenia[25, 26].

To co wydaje się szczególnie ważnym, to fakt że w porównaniu rodziców dzieci chorych i rodziców zdrowych dzieci ukazały się te różnice, których należało się spodziewać w porównaniu ich chorych i zdrowych dzieci Jest to ta sama sytuacja, która wystąpiła, gdy analizowałam wysokość wskaźnika schizofrenii (SCZI) i wskaźnika zaburzeń percepcji i myślenia (PTI) opracowanych przez Exnera; oba te wskaźniki były skonstruowane w celu ujawnienia patologii, tymczasem okazało się, że różnicują one ludzi zdrowych, a nie chorych na schizofrenię [2427]. Jest to szczególnie zaskakujące, że biorąc pod uwagę pojęcie endofenotypu należałoby się spodziewać odwrotnych zależności: wyraźnych cech ocenianych jako patologiczne w grupie osób chorych i tych samych cech, ale mniej nasilonych u ich rodziców. Można próbować wyjaśnić tę sytuację $\mathrm{w}$ ten sposób, że stwierdzane swoistości w wypowiedziach rodziców chorych dzieci wypływają z cech ich osobowości, natomiast swoistości te u ich dzieci rozkwitają w psychozie, by następnie cofnąć się wraz z remisją choroby. Może być i tak, że natura badanych cech jest odmienna od natury cech objętych pojęciem endofenotypu.

Różne jakości ruchu w perceptanalizie są szczególnie ważne dla psychologicznej interpretacji wyników badania testem Rorschacha. Najbardziej pożądany jest ruch swobodny, rozmachowy i pozbawiony negatywnych konotacji emocjonalnych. Ruch skulony traktuje się jako ruch związany z uczuciem frustracji i rozczarowania, a także z postawą poddawania się trudnościom. Ruch niezdecydowany sugeruje bierność osoby badanej, sztywność jej procesów myślowych i niezdecydowanie. Piotrowski podkreśla negatywne aspekty tego typu ruchu, jest to bowiem ruch nie prowadzący do jakiś rezultatów, sam niweluje zmiany, które zdaje się wprowadzać. Niekorzystne według Piotrowskiego jest także spostrzeganie ruchu w formie postawy, mówi ono bowiem według tego badacza o nieufności i niechęci do pozostawania w szczerych, otwartych relacjach z innymi ludźmi. Ruch złożony, o którym mówimy gdy jeden obiekt wykonuje jednocześnie przynajmniej dwa ruchy o różnej jakości traktowany jest jako wyraz ambiwalencji i wewnętrznych konfliktów. Mimo, że wymienione tu jakości ruchów nie są wiązane wprost z lękiem, to jednak Piotrowski przyznaje, że lęk sprzyja spostrzeganiu ruchu skulonego, niezdecydowanego oraz ruchu w formie postawy[32]. Trudno jest wysunąć jakieś przypuszczenie co do związku lęku z ruchem złożonym, zwłaszcza że nie udało mi się znaleźć na ten temat żadnych doniesień, można jednak mniemać że ruch ten jako wyrażający pewne sprzeczności wewnętrzne może łączyć się z lękiem[32]. Dość liczne są dane empiryczne na temat występowania ruchu skulonego[32, 37]. Exner wyróżnia jedynie dwie jakości ruchu; ruch aktywny i ruch pasywny. Ruch aktywny to na pewno ruch rozmachowy według Piotrowskiego, natomiast ruch pasywny w zasadzie obejmuje pozostałe typy ruchu. Ruchy pasywne w systemie Exnera traktowane są jako mniej korzystne i często włączane do różnych wskaźników patologii. Można przypuszczać, że spostrzeganie ruchu rozmachowego raczej nie powinno współwystępować $\mathrm{z}$ lękiem.

Wobec powyższego dość nieoczekiwanym rezultatem okazała się dodatnia, istotna korelacja między lękiem mierzonym wypowiedziami „światłocieniowymi” a liczbą wszystkich spostrzeganych ruchów wziętych globalnie. Wystąpiła ona w całej badanej grupie, w grupie rodziców chorych dzieci oraz w grupie wszystkich matek. Co więcej, liczba wszystkich ruchów rozmachowych, a więc tych które nie „powinny” łączyć się z lękiem, dodatnio korelowała z wypowiedziami „światłocieniowymi” i to we wszystkich uwzględnionych przeze mnie grupach: w całej badanej grupie, w grupie rodziców chorych dzieci, w grupie rodziców zdrowych dzieci, w grupie wszystkich matek i w grupie wszystkich ojców. W grupach dzieci, analizowanych w poprzedniej pracy, ruch rozmachowy nie łączył się z lękiem, ale wszystkie jakości ruchu, wzięte globalnie, istotnie korelowały z lękiem w grupie synów i w całej grupie wszystkich dzieci.

Zgodne z oczekiwaniami zaobserwowano współwystępowanie ruchu skulonego z lękiem w całej badanej grupie (w grupie wszystkich matek zależność ta zbliżała się do istotności) oraz współwystępowanie lęku z ruchami skulonymi w formie postawy (w całej badanej grupie i w grupie rodziców chorych dzieci; w grupie matek związek tych zmiennych zbliżał się do istotności). W grupach dzieci, jak pokazuje pierwsze opracowanie, nie pojawiły się takie współzależności[38]. 
Zaskakującym rezultatem był także brak zależności między ruchem rozmachowym $w$ formie postawy a lękiem. Trudno jest bowiem nie przyjąć możliwości, że to lęk zatrzymuje ruch rozmachowy, niejako „zamraża” go i uniemożliwia jego realizację. Gdy analizowałam związki między lękiem a pojawianiem się różnych jakości ruchów u dzieci badanych par rodziców uzyskałam w jednym przypadku (w grupie wszystkich zdrowych dzieci) przeciwne i zgodne z oczekiwaniami wyniki, a mianowicie wypowiedzi mówiące o ruchu rozmachowym w formie postawy istotnie i dodatnio korelowały z wypowiedziami „światłocieniowymi”. Nie jest łatwo odnieść się do tej niespójności uzyskanych rezultatów; należy liczyć się z tym, że grupy dzieci były za mało liczne, a więc wyniki uzyskane z analizy grup rodziców wydają się bardziej wiarygodne. Faktem pozostaje to, że stwierdzone korelacje w grupie dzieci kształtowały się odmiennie niż w grupie ich biologicznych rodziców.

Konsekwentny układ zależności zaobserwowano w przypadku ruchu niezdecydowanego i ruchu niezdecydowanego $\mathrm{w}$ formie postawy i to zarówno w grupach rodziców jak i w grupach ich dzieci analizowanych w poprzedniej mojej pracy. Nie wystąpiły tu żadne istotne zależności ( jedynie w grupie zdrowych dzieci rho Spearmana zbliżało się do istotności). Myślę, że można próbować wyjaśnić tę sytuację w ten sposób, że ruch niezdecydowany, jako sam niweczący swoje efekty, być może nie jest traktowany przez badanych jako ruch - a raczej jako bezruch, jako utrzymywanie status quo, a szczególnie ruch niezdecydowany w formie postawy, nie jest rozumiany jako ruch. Wszystkie pozostałe ruchy, nawet te złożone i te wyrażane w postawie, prawdopodobnie według badanych są ruchem albo potencjalnym ruchem! Należałoby więc zastanowić się nad psychologicznymi znaczeniami wypowiedzi mówiących o ruchu niezdecydowanym i o ruchu niezdecydowanym $\mathrm{w}$ formie postawy.

We wszystkich analizowanych grupach rodziców konsekwentnie pojawiała się istotna i wysoce istotna korelacja między ruchem złożonym a lękiem. W grupie synów, jak pisałam wcześniej wystąpiła nieoczekiwana ujemna korelacja miedzy lękiem a wypowiedziami mówiącymi o ruchu złożonym, co być może należy potraktować jako artefakt.

Podsumowując należy zauważyć, że najbardziej konsekwentnym rezultatem był związek wszelkich rodzajów ruchu (w tym ruchu rozmachowego) z wypowiedziami „światłocieniowymi” i myślę, że wobec nie zawsze spójnych szczegółowych wyników można skupić się na tej właśnie prawidłowości. Prawidłowość ta dominowała także w analizie grup dzieci. Należałoby więc przyjąć, że lęk motywuje do spostrzegania wszelkich jakości ruchu, a więc nie pełni tylko roli hamującej, ale także jest siłą motywującą, sprzyjającą spostrzeganiu ruchu. Chcąc pozostać na gruncie perceptanalizy można w tym miejscu wyakcentować tę (niejako „dodatkową”) interpretację wypowiedzi „światłocieniowych”, która łączy te wypowiedzi z bogactwem osobowości, z pozytywnie rozumianą złożonością i lepszym wglądem w siebie i w innych ludzi; wypowiedzi „światłocieniowe”, jak podkreśla Piotrowski, mają negatywne znaczenie tylko wówczas, gdy dominują nad pozostałymi sposobami reagowania, szczególnie wtedy, gdy hamują wypowiedzi uwzględniające kolor.

Uzyskane wyniki wskazują na konieczność zastanowienia się nad psychologiczną interpretacją takich jakości ruchu, jak ruch niezdecydowany oraz ruch w formie postawy; być może należałoby spojrzeć bardziej przychylnie na te jakości ruchu. Podobnie pewne nowe światło zostało rzucone na wypowiedzi „światłocieniowe”.

W tym kontekście należy się odwołać do oryginalnych poglądów Rorschacha, który w samej istocie ruchu upatrywał konflikt między spontanicznością a dyscypliną, między żywiołowością a ruchem ujętym w normy, zwyczaje, kulturę. Jak wykazała Akavia[39] fascynacja Rorschacha ruchem była w istocie fascynacją tym właśnie konfliktem. Stwierdzone związki spostrzeganego ruchu z wypowiedziami świadczącymi o przeżywaniu lęku odpowiada rozumieniu ruchu zgodnie z myślą Rorschacha. Ruch to zjawisko dialektyczne, to walka między dwoma przeciwstawnymi tendencjami, tendencją do wolności i tendencją do kontroli[39-41]. Konflikt ten jest według Rorschacha warunkiem wewnętrznego, twórczego rozwoju (stąd zrozumiała wydaje się obecność lęku) a analiza percepcji ruchu daje nam wgląd w strukturę ja badanej osoby, w strukturę jej selfu. [39-41]. Przyjęcie pozytywnej roli dialektyki ruchu prowadzi też do koniecznej zmiany w psychologicznej interpretacji ruchu wyrażonego w postawie.

W końcu należy podkreślić, że najciekawszym i najwyrazistszym ustaleniem okazały się różnice między rodzicami chorych dzieci a rodzicami zdrowych dzieci w liczbie wypowiedzi mówiących o ruchu ludzkim. Poszukiwanie różnic $\mathrm{w}$ jakości ruchów nie przyniosło spodziewanych rezultatów. Jedynie ojcowie zdrowych dzieci, częściej niż ojcowie dzieci chorych, mówili o ruchu skulonym w formie postawy, co nie do końca pozostaje spójne z koncepcją ruchu opracowaną przez Piotrowskiego. Uzyskane wyniki natomiast, w pewnym stopniu potwierdzają poglądy Jamesa P. Choca i Edwarda D. Rossiniego. Autorzy ci twierdzą, że rozróżnienie nawet między tak podstawowymi jakościami ruchu, jak ruch aktywny i ruch pasywny, choć przydatne w klinicznej ocenie jednostek, nie znalazło potwierdzenia w szerszych badaniach empirycznych; samo spostrzeganie ruchu, a zwłaszcza ruchu postaci ludzkiej, nadal jednak pozostaje 
zmienną bardzo istotną[42].

\section{Konkluzje}

1. Grupa rodziców $\mathrm{z}$ dzieckiem chorym na schizofrenię różniła się od grupy rodziców mających tylko zdrowe dzieci w większym stopniu, niż poddana takiemu samemu porównaniu grupa ich biologicznych, chorych dzieci odniesiona do grupy dzieci z rodzin kontrolnych.

2. Rodzice chorych dzieci ujawnili mniej wyraziście ukształtowaną rolę prototypową oraz dość liczne oznaki trudności w ekspresji tej roli. Różnice między ojcami dzieci chorych i ojcami dzieci zdrowych były większe niż różnice między matkami.

3. Rodzice chorych dzieci, a szczególnie ojcowie, ujawnili wyższy poziom lęku mierzonego liczbą wypowiedzi „światłocieniowych”.

4. Analiza współwystępowania wypowiedzi mówiących o różnych jakościach ruchu i wypowiedzi interpretujących światłocień pozwoliła, jak myślę, na lepszy wgląd w psychologiczne znaczenia poszczególnych jakości ruchu spostrzeganego w plamach atramentowych (szczególnie konieczne jest nowe spojrzenie na ruch niezdecydowany i ruch niezdecydowany $\mathrm{w}$ formie postawy). Wskazałam na potrzebę powrotu do oryginalnej myśli Rorschacha, który traktował ruch i jego percepcję jako konflikt między przeciwstawnymi tendencjami: dążeniem do wolności i dążeniem do kontroli.

\section{Conflict of interest}

The author has declared no conflict of interest.

\section{References:}

1. Hirsh SR, Leff JP. Abnormalites In parents of schizoprenics London, New York, Toronto; Oxford University press: 1975.

2. Wynne IC, Singer MT. Thought disorder and family relations of schizophrenics. Archives of general Psychiatry, 1963; 9: 191198.

3. Alanen JO. Schizofrenia. Jej przyczyny I leczenie dostosowane do potrzeb. Warszawa; Instytut Psychiatrii i Neurologii: 2000.

4. Scheflen AE. Levels of schizophrenia. New York; Brunner/Mazel Publishers: 1981.

5. Alba CS. Family changing process: Integration of two modalities of Rorschach test administration. Rorschachiana, 1994; (19): 47-60.

6. Drat-Ruszczak K. Wpływ indukcji postawy niezależności I związania z rodziną na przetwarzanie informacji społecznej w schizofrenii. Przegląd Psychologiczny, 1991; 34(2): 271-291.

7. Drat-Ruszczak K. Priming of on assertive or submissive orientation toward the family and the processing of family related information in schizophrenia. Polish Psychological Bulletin. !994; 25 (1): 43-57.

8. Chuchra M. Rodzina $\mathrm{z}$ dorosłym dzieckiem chorym na schizofrenię. Lublin; Wydawnictwo KUL: 2010.

9. Chrząstowski Sz. Nasilenie bliskości i intruzywności w ocenie matek synów leczących się z powodu schizofrenii lub uzależnienia od narkotyków. Psychiatria Pol. 2008; 42 (3): $417-$ 429.

10. Chrząstowski Sz. Związki między brzemieniem rodziców osób z rozpoznaniem schizofrenii lub zaburzeń osobowości a kształtowaniem się relacji w rodzinie. Psychiatria Pol. 2006; 40(5): 901-911.

11. Budzyna- Dawidowski P, Rostworowska M, de Barbaro B, Wojnar M. The koncept of Expressem emotions In a cultural context: A polish perspective. Psychoterapia. 1991; 76(1): 8589.

12. Czabała JCz. Rodzina a zaburzenia psychiczne. Kraków; IPN: 1988.

13. De Barbaro B, Ostoja-Zawadzka K, Drożdżowicz L, Cechnicki a. Beyond the myth of the "overprotective mother" to „overburdening mother”. Psychoterapia, 76 (2): 35-37.

14. Hinze B, Bembenek A, Küchn-Dymecka A, Wrońska A, Wciórka J. Dysfunkcja uwagi u osób chorych na schizofrenię i ich krewnych pierwszego stopnia. Psychiatr Pol. 2004a; 38(5): 847-860.

15. Hintze B, Küchn-Dymecka A, Wrońska A, Wciórka J. Dysfunkcja uwagi u osób chorych na schizofrenię i ich krewnych pierwszego stopnia. Psychiat Pol. 2004 b; 38(5): 861-873.

16. Makara-Studzińska M, Łoś R. Badania porównawcze między osobami z różnymi zaburzeniami psychicznymi a ich zdrowym rodzeństwem. Post Psychiatr Neurol. 2012; 21(3): 929-938.

17. Motak E. Klimat emocjonalny w rodzinie a poziom umiejętności społecznych chorych na schizofrenię. Psychiatr Pol. 1996; 30(6): 929-938.

18. Mroziak B. Rodzina a etiologia i przebieg schizofrenii ( przegląd wyników badań). Psychologia Wychowawcza, 1983; (5): 543557.

19. Mroziak B. percepcja interpersonalna w rodzinach. Psychologia Wychowawcza, 1995; (2): 143-153.

20. Pawęzka J, Karakuła H, Grzywa A. Zaburzenia pamięci operacyjnej w schizofrenii-cz. 2. Powiązanie z innymi objawami psychopatologicznymi. Bad nad schizofrenią, 2009; 10 (1): 5257.

21. Brüne M, Juckel G. Poznanie społeczne w schizofrenii. Mentalizacja i poziom funkcjonowania psychospołecznego. Psychiatria po dyplomie, 2010; 7 (6): 27-31.

22. Hunca-Bednarska A, Masiak M. Kompetencja społeczna w schizofrenii-analiza niektórych wypowiedzi kobiet chorych na schizofrenię uzyskanych podczas badania testem $\mathrm{H}$. Rorschacha. Twój Magazyn medyczny. Neurologia i Psychiatria, 2003; 8 (4): 19-25.

23. Hunca-Bednarska A. poczucie wyobcowania u rodziców osób chorych na schizofrenię paranoidalną. Roczniki Psychologiczne, 2008; 11 (1): 77-94.

24. Hunca-Bednarska A. Zakłócenia procesów mediacji i konceptualizacji podczas formowania wypowiedzi w teście Hermanna Rorschacha. Wskaźnik schizofrenii-SCZI. Annales UMCS, sectio J, 2008; 21: 95- 112.

25. Hunca-Bednarska A. Zakłócenia procesów mediacji i konceptualizacji podczas formowania wypowiedzi w teście Hermanna Rorschacha u rodziców mających chore na schizofrenię paranoidalną dziecko. Roczniki Teologiczne. Zeszyty Naukowe o Rodzinie, 2008; 55 (5): 247-264.

26. Hunca-Bednarska A. PTI - wskaźnik zaburzeń percepcji i myślenia według J.E. Exnera: badanie rodziców osób chorych na schizofrenię paranoidalną za pomocą testu Rorschacha. Post Psychiatr Neurol. 2008; 17 (4): 305-312.

27. Hunca-Bednarska A. J.E. Exnera wskaźnik zaburzeń i myślenia 
- PTI. Badanie porównawcze rodziców osób chorych na schizofrenię paranoidalną oraz rodziców mających tylko zdrowe dzieci. Bad nad schizofrenią, 2008; 9 (9): 62- 74.

28. Hunca-Bednarska A. Mechanizm obronny intelektualizacji. Badanie porównawcze rodziców osób chorych na schizofrenię paranoidalną oraz rodziców mających tylko zdrowe dzieci. Bad nad schizofrenią, 2007; 8 (8): 53-61.

29. Szafraniec J. Metoda Rorschacha w psychodiagnozie schizofrenii. Warszawa; Wydawnictwo Akcydensowe: 1985.

30. Kalla O, Wahlström J, Aaltonen J, Holma J,Tuimala P, Mattlar CE. Rorschach characteristics and comparison of first- episode psychotic patients In Finland and Spain. Rorschachiana, 2004; 26 (1); 63-84.

31. Grzywak-Kaczyńska M. Podręcznik do metody Rorschacha. Lublin; Wydawnictwo KUL: 2006.

32. Piotrowski Z. Perceptanalisis. Philadelphia; Ex Libris: 1979.

33. Blatt SJ, Brenneis CB, Schimek JG, Glick M. Normal development and psychopathological impairment of the concept of the object on the Rorschach. Journal of Abnormal Psychology, 1976; 85 (4): 364- 373.

34. Exner JE. The Rorschach Comprehensive System. Hoboken, New York; John Wiley and sons: 2003.

35. Lesniak F. Perceptanaliza w perspektywie pozytywnej dezintegracji. Warszawa; PTHP: 1994

36. Hunca-bednarska A. Próba jakościowej analizy wypowiedzi dotyczących ludzi spostrzeganych na trzeciej tablicy testu $\mathrm{H}$. Rorschacha. Bad nad schizofrenią, 2006; 7(7): 242-258.

37. Flahault C, Sultan S. On being a child of an ill parent: A Rorschach investigation of adaptation to parental cancer compared to other illnesses. Rorschachiana, 2010; 31 (1): 43-69.

38. Hunca-Bednarska A. Wypowiedzi "ruchowe " w tescie rorschacha. Część 1. Badanie osób zdrowych i osób chorych na schizofrenie.

39. Akavia N. Subjectivity in Motion. Life, Art and Movement in the Work of Hermann Rorschach. New York, London; Rontledge, Taylor and Francis Group: 2013.

40. Guenther K. Review of Naamah Akavia, Subjectivity in motion. Life, art, and movement in the work of Hermann Rorschach, routledge, 2013. Berichte zur Wissenschaaftsgeschiche, 2013; 36 (4): 382-384.

41. Hunca-Bednarska A. Koncepcja ruchu w tescie Hermanna Rorschacha. Refleksje nad książką Naamah Akavii: Subjectivity in motion. Life, art, and movement in the work of Hermann Rorschach. Curr Probl Psychiatry, 2015; 16 (2): 113-1123.

42. Choca JP, Rossini ED. Assessment Using the Rorschach Inkblot Test. Washington; American psychological Association: 2018.

\section{Corresponding author}

\section{Anna Hunca - Bednarska \\ e-mail: bednarskim5@wp.pl}

Otrzymano: 18.04.2019

Zrecenzowano:11.06.2019

Przyjęto do druku:17.06.2019 